Prepared for the U.S. Department of Energy under Contract DE-AC05-76RL01830

\title{
Analysis of Radioactive Releases During Proposed Demolition Activities for the 224-U and 224-UA Buildings
}

Report to $\mathrm{CH} 2 \mathrm{M}$ HILL Plateau Remediation Company
BA Napier
KE Joyce
JP Rishel
DJ Strom
JG Droppo Jr.

December 2010

Pacific Northwest

NATIONAL LABORATORY

Proudly Operated by Battelle Since 1965 


\title{
DISCLAIMER
}

This report was prepared as an account of work sponsored by an agency of the United States Government. Neither the United States Government nor any agency thereof, nor Battelle Memorial Institute, nor any of their employees, makes any warranty, express or implied, or assumes any legal liability or responsibility for the accuracy, completeness, or usefulness of any information, apparatus, product, or process disclosed, or represents that its use would not infringe privately owned rights. Reference herein to any specific commercial product, process, or service by trade name, trademark, manufacturer, or otherwise does not necessarily constitute or imply its endorsement, recommendation, or favoring by the United States Government or any agency thereof, or Battelle Memorial Institute. The views and opinions of authors expressed herein do not necessarily state or reflect those of the United States Government or any agency thereof.

\author{
PACIFIC NORTHWEST NATIONAL LABORATORY \\ operated by \\ BATTELLE \\ for the \\ UNITED STATES DEPARTMENT OF ENERGY \\ under Contract DE-AC05-76RL01830
}

Printed in the United States of America

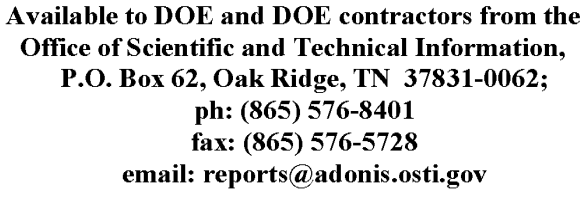

Available to DOE and DOE contractors from the Office of Scientific and Technical Information,

P.O. Box 62, Oak Ridge, TN 37831-0062;

ph: (865) 576-8401

fax: (865) 576-5728

email: reports@adonis.osti.gov

\footnotetext{
Available to the public from the National Technical Information Service, U.S. Department of Commerce, 5285 Port Royal Rd., Springfield, VA 22161 ph: (800) 553-6847 fax: $(703) 605-6900$ email: orders(antis.fedworld.gov online ordering: http://www.ntis.gov/ordering.htm
}

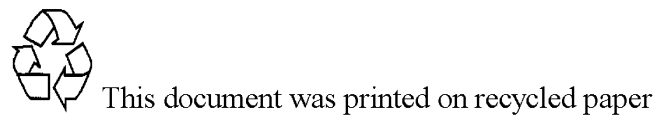


PNNL-18332

Addendum

\title{
Analysis of Radioactive Releases During Proposed Demolition Activities for the 224-U and 224-UA Buildings
}

\author{
Report to CH2M HILL Plateau Remediation Company
}

$\begin{array}{ll}\text { BA Napier } & \text { KE Joyce } \\ \text { JP Rishel } & \text { DJ Strom } \\ \text { JG Droppo Jr. } & \end{array}$

December 2010

Prepared for

the U.S. Department of Energy

under Contract DE-AC05-76RL01830

Pacific Northwest National Laboratory

Richland, Washington 99352 



\section{Summary}

A post-demolition modeling analysis is conducted that compares during-demolition atmospheric concentration monitoring results with modeling results based on the actual meteorological conditions during the demolition activities. The 224-U and 224-UA Buildings that were located in the U-Plant $\mathrm{UO}_{3}$ complex in the 200 West Area of the Hanford Site were demolished during the summer of 2010. These facilities converted uranyl nitrate hexahydrate (UNH), a product of Hanford's Plutonium-Uranium Extraction (PUREX) Plant, into uranium trioxide $\left(\mathrm{UO}_{3}\right)$.

This report is an addendum to a pre-demolition emission analysis and air dispersion modeling effort that was conducted for proposed demolition activities for these structures. ${ }^{1}$ That pre-demolition modeling of the 224-U and 224-UA Buildings demolition assumed there would be some release of radioactive material into the air based on the details of the planned demolition activities.

Historical monitoring results that include the recent periods of active demolition are analyzed for three stations located around the facilities. The monitoring data during demolition indicate slightly elevated levels of gross alpha that may be the result of demolition-related uranium releases. The observed increments over background are greatest for the monitoring station location N551. The analysis shows that the elevated concentrations at this station represent statistically significant increments over the historical background for that station.

The objective of the post-demolition modeling is to determine how well the observed patterns of concentration increments in the monitoring data can be replicated by air dispersion modeling using the actual meteorological conditions. The air dispersion modeling is conducted assuming a constant unit release rate spread out spatially over the assumed emission areas and temporally over each of the 2-week monitoring periods.

These results are highly consistent with the interpretation that the slightly elevated concentrations are the result of the demolition activities. The results show the model predicts larger concentration increments at the N551 location, and much smaller increments at the other two monitoring stations. There is close agreement between the variations of observed concentration increments and of normalized predicted concentration increments. The agreement with the monitoring data is slightly better assuming the emissions are from the more-contaminated baghouse demolition areas rather than from the entire footprint of the demolished buildings.

The validity and value of the pre-demolition computations for planning demolition activities are further indicated by the agreement between the predicted pre-demolition concentration increments and the actual concentration increments observed during the demolition. Although concentrations were not computed explicitly for the specific monitoring station locations, the pre-demolition analysis did provide a basis for an expectation for the magnitude of concentration increments that was observed at these locations during the demolition activities.

\footnotetext{
${ }^{1}$ The original report can be found at http://www.pnl.gov/main/publications/external/technical_reports/PNNL-18332.pdf
} 



\section{Acknowledgments}

The authors would like to extend their appreciation to Richard Bloom of the CH2M HILL Plateau Remediation Company for financial and technical support of this work. Meteorological data from the Hanford Meteorological Station for the period was provided by Ken Burk, Pacific Northwest National Laboratory. This work was funded by CH2M HILL Plateau Remediation Company under the U.S. Department of Energy Contract DE-AC05-76RL01830. 



\section{Acronyms and Abbreviations}

$\begin{array}{ll}\text { AERMOD } & \text { American Meteorological Society/Environmental Protection Agency Regulatory } \\ & \text { Model } \\ \text { CHPRC } & \text { CH2M HILL Plateau Radiation Company } \\ \text { DOE } & \text { U.S. Department of Energy } \\ \text { EPA } & \text { U.S. Environmental Protection Agency } \\ \text { ERDF } & \text { Environmental Restoration Disposal Facility } \\ \text { g } & \text { gram } \\ \text { PDF } & \text { probability density function } \\ \text { PNNL } & \text { Pacific Northwest National Laboratory } \\ \text { PUREX } & \text { plutonium-uranium extraction } \\ \text { UNH } & \text { uranyl nitrate hexahydrate } \\ \text { UO }_{3} & \text { uranium trioxide }\end{array}$





\section{Contents}

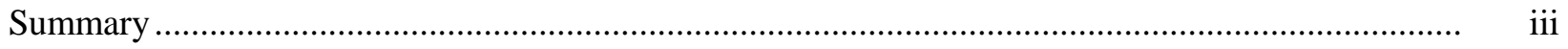

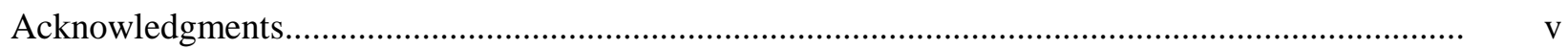

Acronyms and Abbreviations ....................................................................................................... vii

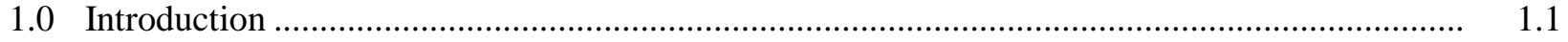

2.0 Dispersion Conditions During Demolition Activities ....................................................... 2.1

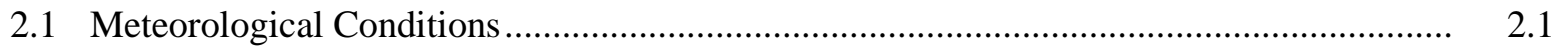

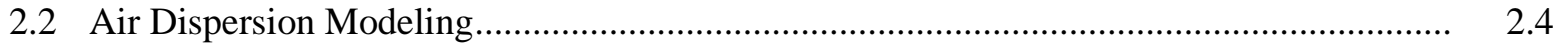

3.0 Analysis of Gross Alpha Measurements near $\mathrm{UO}_{3}$ Plant Demolition ..................................... 3.1

4.0 Modeled and Monitored Data Comparison .............................................................................

5.0 Conclusions ….............................................................................................................. 5.1

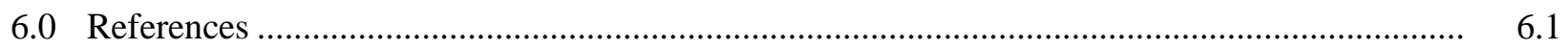

Appendix A - Emission Scenarios Analysis............................................................................... A.1

Appendix B - Building Area Source Predicted Concentrations .......................................................... B.1

Appendix C - Baghouse Source Predicted Concentrations ........................................................ C.1 


\section{Figures}

1.1 Aerial View of the 224-U and 224-UA Buildings and Surroundings Before Demolition............ 1.2

1.2 Location of Continuous Air Monitors Around the U-Plant Complex........................................... 1.2

2.1 Wind Rose for Hanford 200 West Area for Working Hours for the Period June 28-July 12, 2010

2.2 Wind Rose for Hanford 200 West Area for Working Hours for the Period July 13-26, 2010

2.3 Wind Rose for Hanford 200 West Area for Working Hours for the Period July 26-August 9, 2010

2.4 Wind Rose for Hanford 200 West Area for Working Hours for the Period August 9-23, 2010

2.5 Wind Rose for Hanford 200 West Area for Working Hours for the Period August 23-September 7, 2010.

2.6 Hourly Predicted Air Concentrations as a Function of Wind Direction for Scenario 1.

2.7 Hourly Predicted Air Concentrations as a Function of Wind Direction for Scenario 2.

2.8 Scenario 1 - Average Predicted Concentration Pattern for the 10-Week Demolition Period

2.9 Scenario 2 - Average Predicted Concentration Pattern for the 10-Week Demolition Period...

3.1 Comparison of Probability Density Functions for Five Measurements of Gross Alpha Concentration from Monitoring Station N551 to the Background of All Measurements from that Station

3.2 Statistical Separation of Variability and Uncertainty of Airborne Gross Alpha Measurements for Monitoring Station N551

3.3 Statistical Separation of Variability and Uncertainty of Airborne Gross Alpha Measurements for Monitoring Stations N155, N168, and N550

4.1 Comparison of Predicted and Observed Concentrations of Gross Alpha at the Air Monitoring Locations for Scenario 1

4.2 Comparison of Predicted and Observed Concentrations of Gross Alpha at the Air Monitoring Locations for Scenario 2

\section{Tables}

1.1 Start and End Dates and Times for the Five, 2-Week Monitoring Periods.....

2.1 Predicted Average Air Concentrations for Five, 2-Week Monitoring Periods 2.6

3.1 Recent Gross-Alpha Measurement Results for Three Air Monitoring Locations 


\subsection{Introduction}

A post-demolition modeling analysis is conducted comparing during-demolition atmospheric monitoring results with modeling results based on the actual meteorological conditions during the demolition activities. The 224-U and 224-UA Buildings (Figure 1.1) that were located in the U-Plant $\mathrm{UO}_{3}$ complex in the 200 West Area of the Hanford Site were demolished during the summer of 2010. These facilities converted uranyl nitrate hexahydrate (UNH), a product of Hanford's Plutonium-Uranium Extraction (PUREX) Plant, into uranium trioxide $\left(\mathrm{UO}_{3}\right)$. This report is an addendum to the predemolition analysis reported by Napier et al. (2009). Detailed information on the air dispersion modeling approach and assumptions is documented in that report. ${ }^{1}$

The $\mathrm{UO}_{3}$ Plant consisted of two major buildings: the 224-U Building (built in 1943 as part of the plutonium processing construction but converted to uranyl nitrate concentration conversion processing) and the 224-UA Building built in 1956 to house new continuous calciners. The 224-U Building housed the concentrating and nitric acid recovery equipment. In addition to the calciners, the 224-UA Building housed the powder-handling tower and the $\mathrm{UO}_{3}$ powder-packaging machinery (used to load T-hoppers). During deactivation in 1993, most of the radioactive material was removed; the material that remained was primarily residual uranium tri-oxide dust in the calciners and powder-handling systems. The U.S. Department of Energy (DOE) and CH2M HILL Plateau Radiation Company (CHPRC) demolished the structures beginning in July 2010.

The 224-U Building was 197 feet long, 60 feet wide, and 40 feet tall. It was divided along its length by a 12-inch-thick concrete shield wall into a gallery side and a canyon side. The gallery side was a three-story reinforced concrete frame structure with concrete floor and roof slabs. The 224-UA Building was approximately 75 feet long and 67 feet wide. The floor slab and footing were reinforced concrete. Debris from these two structures is being disposed of at the Environmental Restoration Disposal Facility (ERDF) in the 200 Areas.

This report considers the conditions during the actual demolition efforts in terms of the monitoring results observed during the demolition operations. The objective is to determine if the slightly elevated concentrations observed at one of the three monitoring stations can be attributed to the demolition activities.

Routine air sampling measurements have been made for many years at permanent monitoring stations on the Hanford Site. A series of 2-week integrated air samples performed at permanent monitoring stations near the demolition activities at the 224-U and 224-UA Buildings has been evaluated. Measurements made at the N155, N168, N550, and N551 locations have been compared with dispersion modeling results for the period of building demolition. These locations are identified in Figure 1.2. The 224-U and 224-UA Buildings are those immediately to the east of station N551. These buildings are in a location surrounded by other large structures, which complicates atmospheric dispersion modeling. The location of the $\mathrm{UO}_{3}$ complex within the buildings is highlighted in Figure 1.2. In addition to the four monitoring stations, locations near the southwest and northeast corners of the 224-U Building were also modeled.

\footnotetext{
${ }^{1}$ The original report can be found at http://www.pnl.gov/main/publications/external/technical_reports/PNNL-18332.pdf
} 


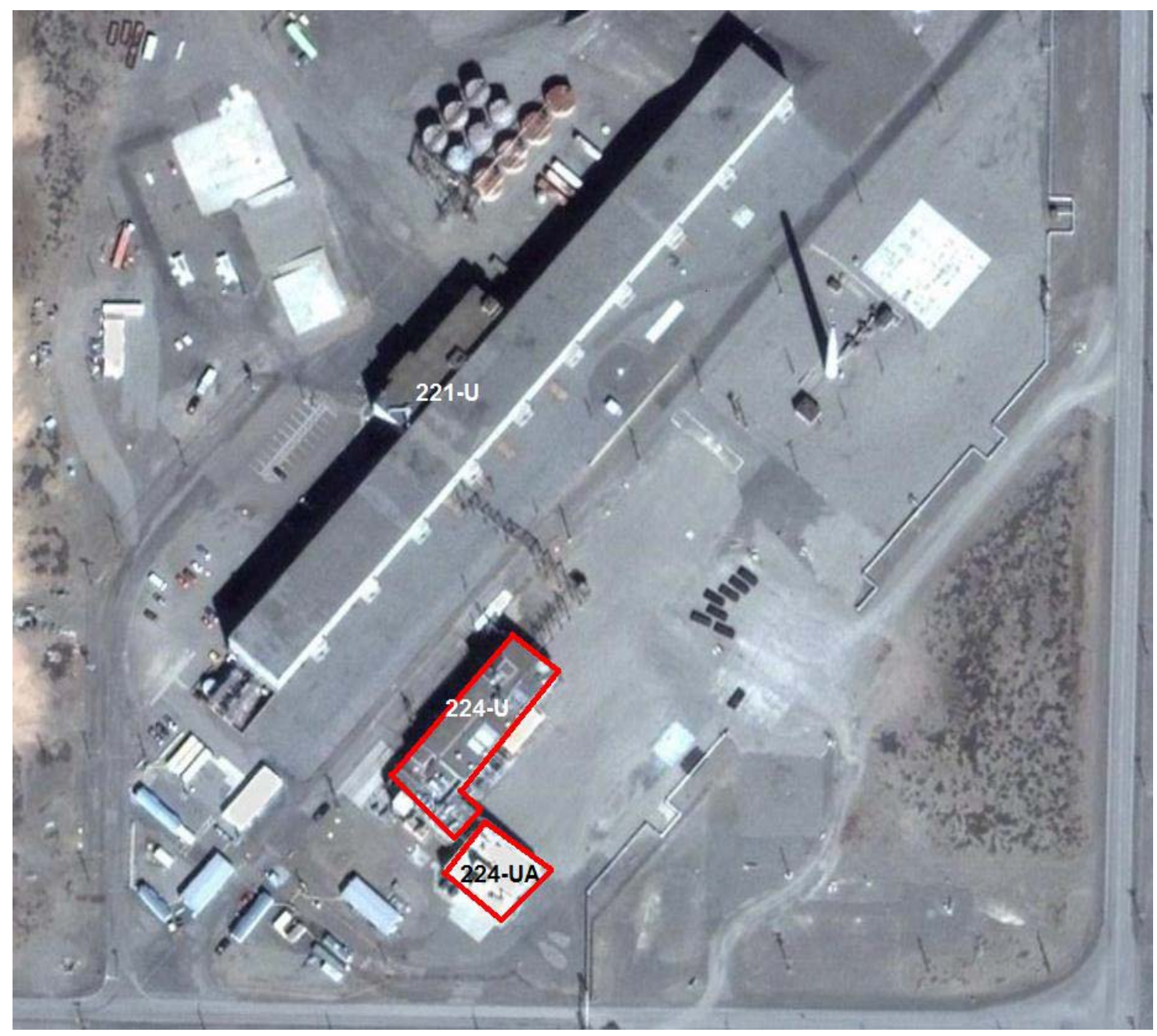

Figure 1.1. Aerial View of the 224-U and 224-UA Buildings and Surroundings Before Demolition

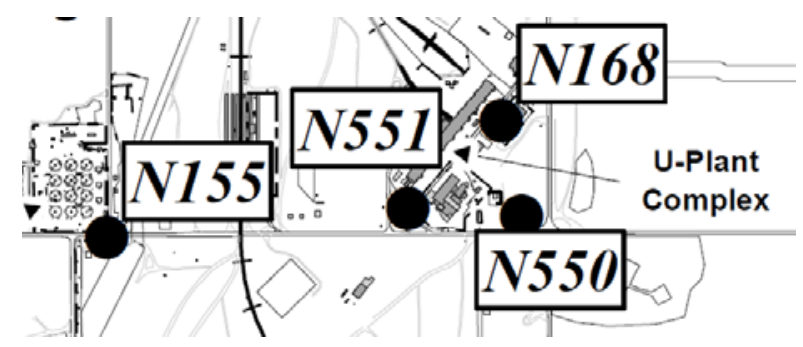

Figure 1.2. Location of Continuous Air Monitors Around the U-Plant Complex

The demolition activities involving the destruction of the U-Plant, which occurred over a 10-week period, are considered in this report. Monitoring data are available at 2-week intervals. Therefore, there are five, 2-week periods considered in this report. The start and end dates for these five periods are shown in Table 1.1. Samples were changed in early morning, typically between 8 and 9 a.m.. 
Table 1.1. Start and End Dates and Times for the Five, 2-Week Monitoring Periods

\begin{tabular}{ccc}
\hline Period Number & Start Date & Stop Date \\
\hline 1 & $06 / 28 / 10$ & $07 / 12 / 10$ \\
2 & $07 / 12 / 10$ & $07 / 26 / 10$ \\
3 & $07 / 26 / 10$ & $08 / 09 / 10$ \\
4 & $08 / 09 / 10$ & $08 / 24 / 10$ \\
5 & $08 / 24 / 10$ & $09 / 07 / 10$ \\
\hline
\end{tabular}

Section 2 of this report considers the dispersion conditions modeled during the demolition activities. Section 3 analyzes the gross alpha monitoring results in terms of the statistical significance of the slightly elevated concentrations observed at one of the monitoring stations during the demolition activities. Section 4 compares the monitoring data and dispersion modeling results. Section 5 gives the conclusions, and Section 6 lists the references. 


\subsection{Dispersion Conditions During Demolition Activities}

To model the air dispersion conditions, assumptions must be made about both when and where the emissions occur. A scoping analysis, documented in Appendix A, was made to determine how well different modeling assumptions will emulate the station-to-station trends observed in the monitoring data. The trends predicted for each of the four alternative emission scenarios that were considered. Two "most likely” emission scenarios were defined. These both assume that the emissions occur during the demolition working hours:

- Scenario 1 assumes the emissions come from the footprint of the building structures.

- Scenario 2 assumes the emissions come from the areas with the highest uranium contamination.

Atmospheric modeling of the demolition, using a unit source term and actual meteorological conditions, was conducted for these two scenarios to develop the likelihood that a release would result in concentrations near one of the monitoring station locations. The modeling assumed releases occurred during standard work days (Monday through Friday) and times (9:00 a.m. to 12:00 p.m. and 1:00 to 4:00 p.m.) throughout a 10-week period beginning on June 28, 2010, and continuing through September 6, 2010. Because monitoring data were available at 2-week intervals, there are five, 2-week periods analyzed in this report (see Table 1.1 for period dates). The 10 weeks considered in this analysis corresponds to the beginning of demolition activities at U-Plant.

\subsection{Meteorological Conditions}

Meteorological data were analyzed for Hanford Meteorological Station \#19 (Plutonium Finishing Plant-200W), which is the closest, most representative station near U-Plant. Meteorological conditions during the five, 2-week periods noted in Table 1.1 are shown in Figure 2.1 through Figure 2.5. The data are plotted as wind roses, which synthesize wind direction and wind speed frequencies. Petal placement represents the direction from which the wind is blowing, and the petal color represents the speed. Frequencies (or percentage of time) are denoted by the dashed, concentric circles emanating outwards from the center of the wind rose. For reference, the directions to the N155, N168, N550, and N551 monitoring stations are indicated on the outer-most frequency circle.

The predominant wind directions during the hours of demolition activity vary between five, 2-week time periods shown in Figure 2.1 through Figure 2.5, respectively. Predomiant winds occur in directions occurring clockwise between northwest to east-southeast. The approximate directions for air flow from the demolition activity to each of the monitoring stations are indicated on these plots. For example, in Figure 1.2, these wind directions would result in material being transported toward monitoring station N551 (to the southwest), with some modification due to the presence of U-Plant structures. Periods 2, 3, and 4 have a higher percentage of calms than Periods 1 and 5. As shown in Figure 2.1 and Figure 2.5 (periods 1 and 5, respectively), the winds are predominately from the northwesterly direction, so transport toward N550 would have been more likely. These two periods are also dominated by faster winds on average. 


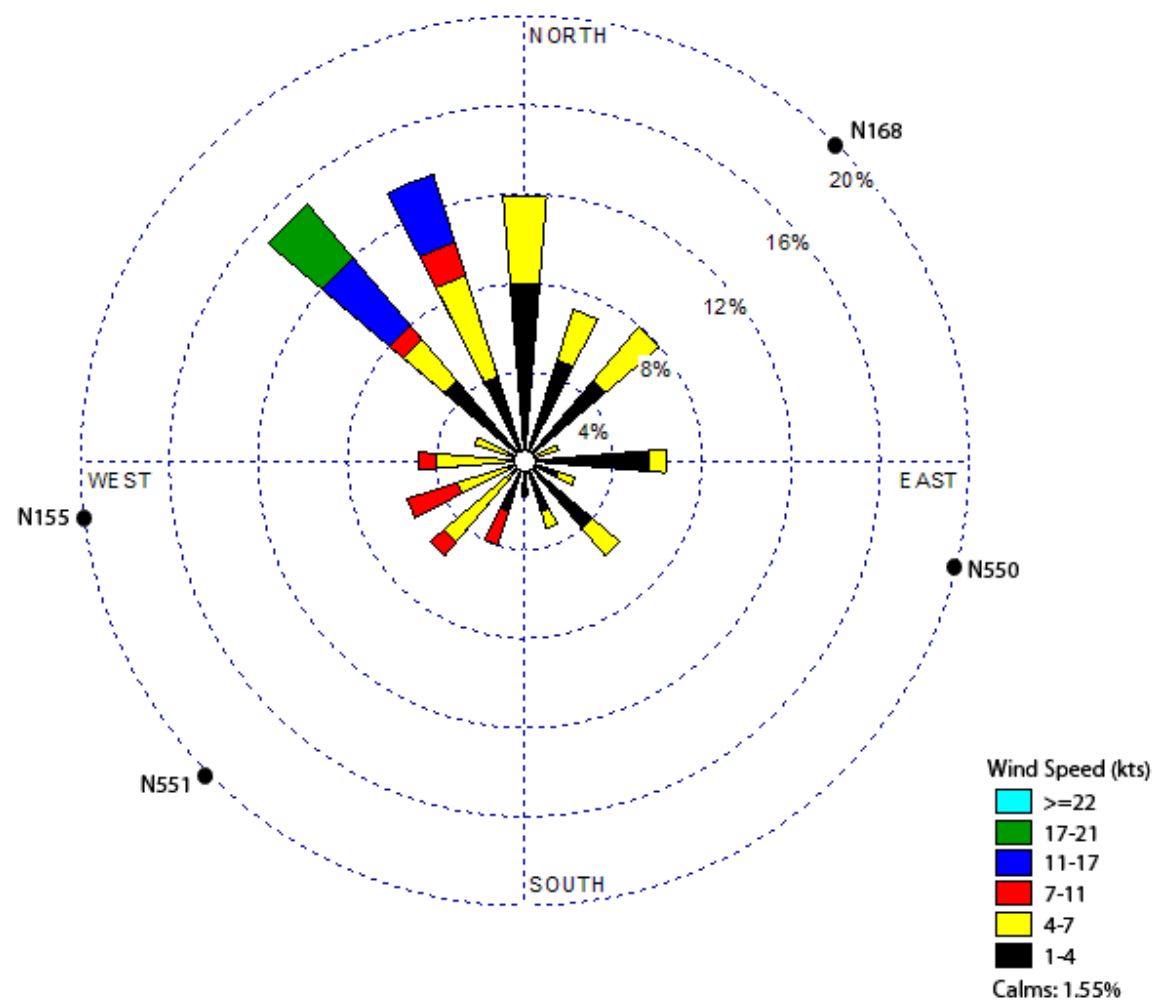

Figure 2.1. Wind Rose for Hanford 200 West Area for Working Hours for the Period June 28-July 12, 2010

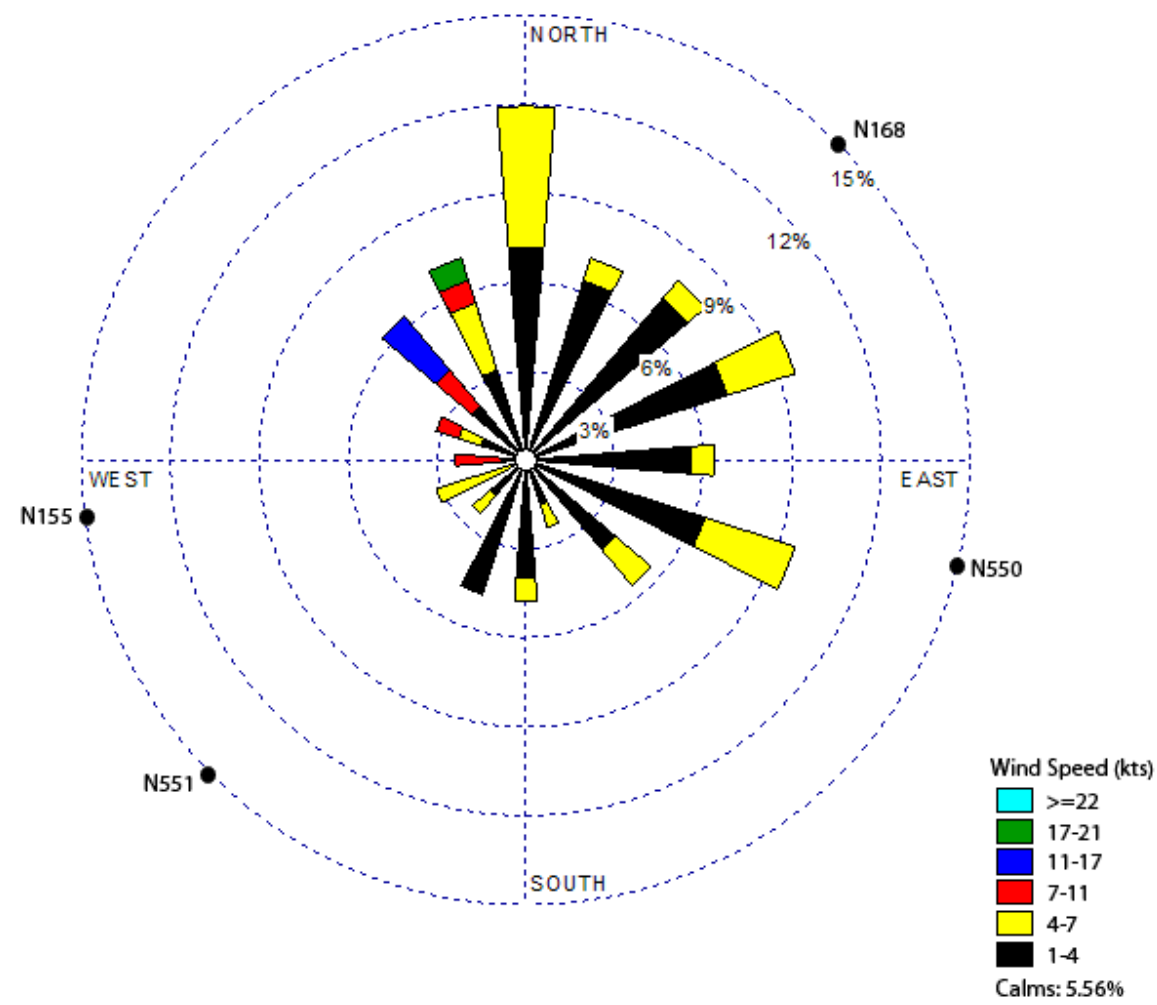

Figure 2.2. Wind Rose for Hanford 200 West Area for Working Hours for the Period July 13-26, 2010 


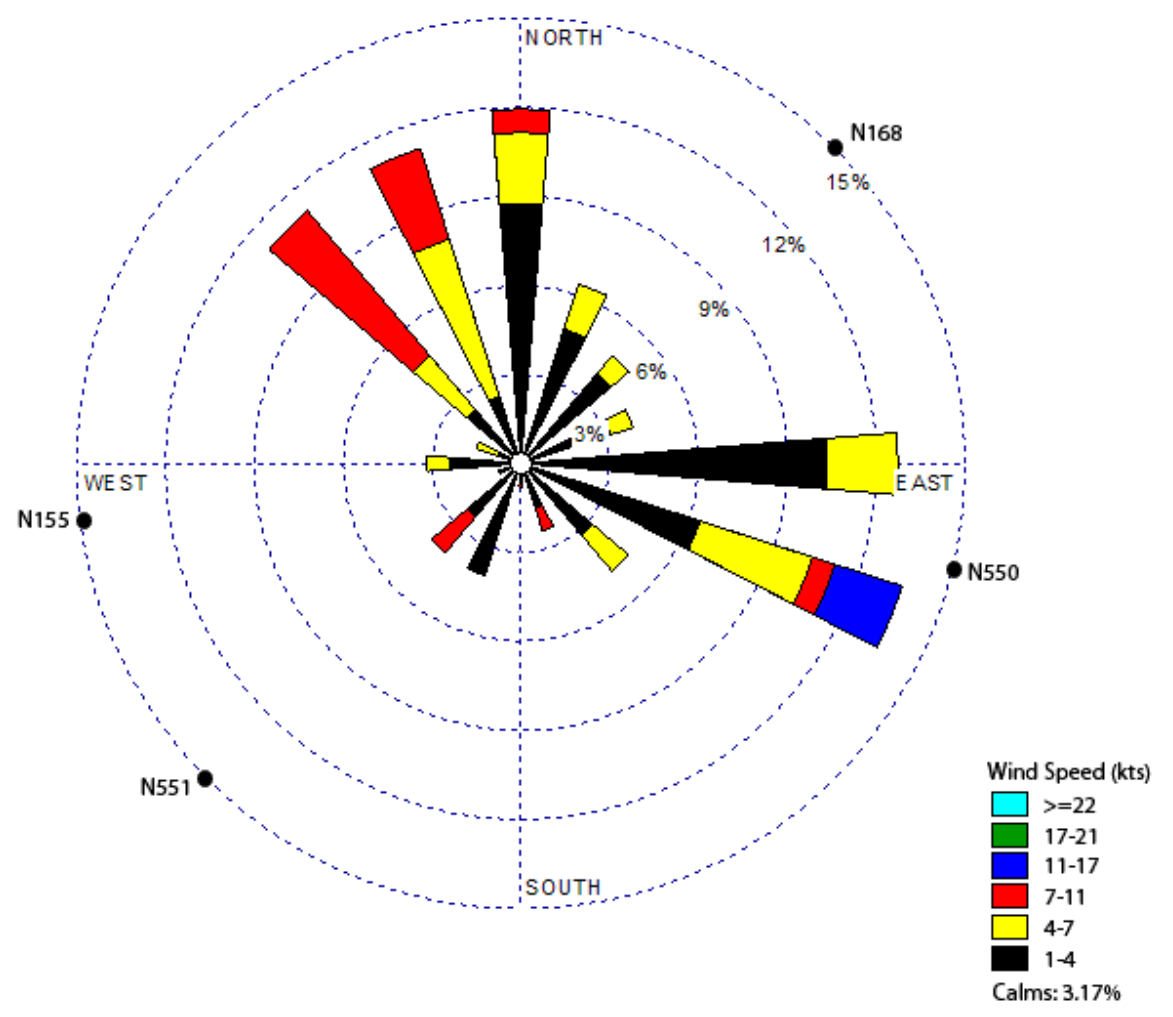

Figure 2.3. Wind Rose for Hanford 200 West Area for Working Hours for the Period July 26-August 9, 2010

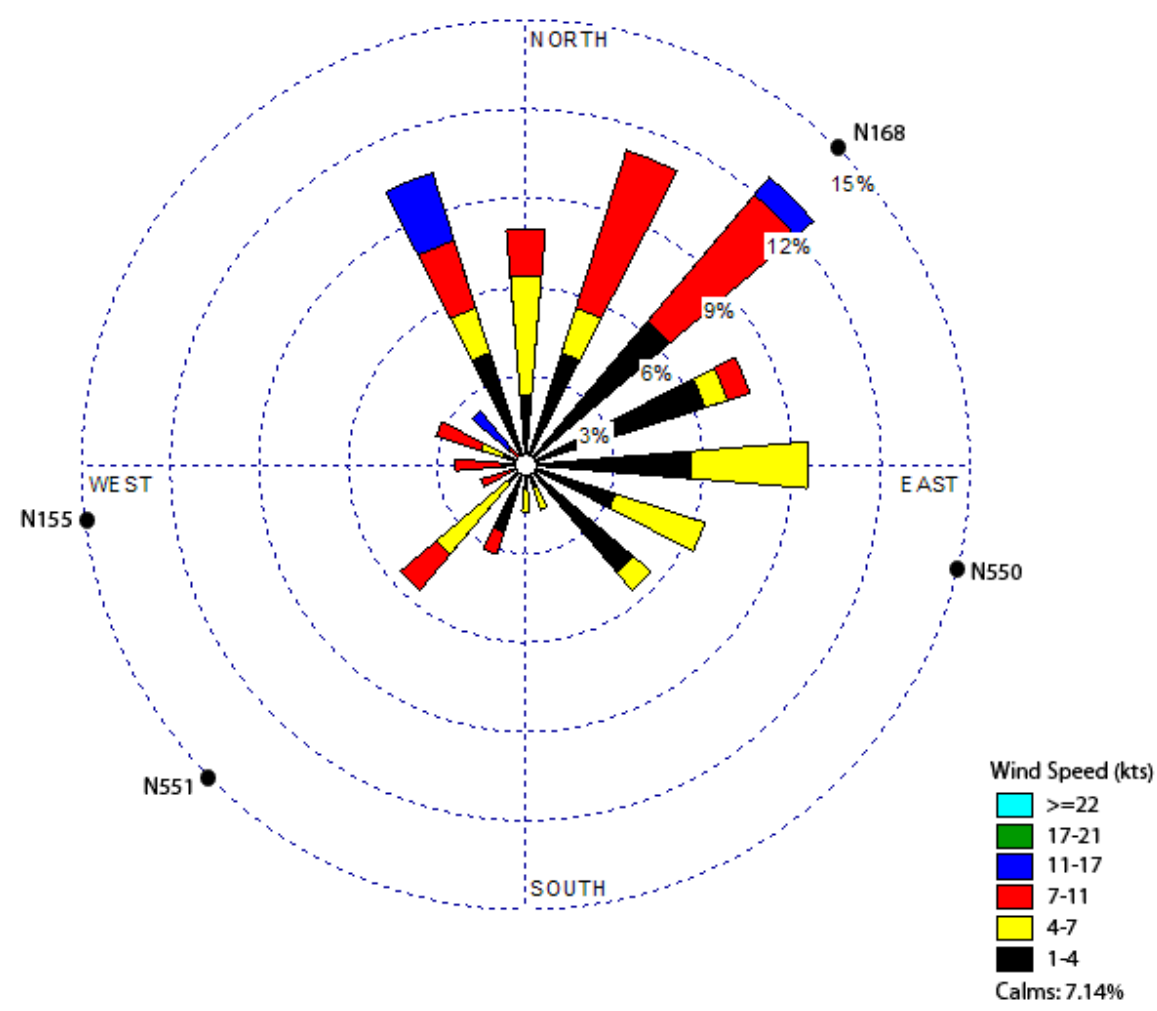

Figure 2.4. Wind Rose for Hanford 200 West Area for Working Hours for the Period August 9-23, 2010 


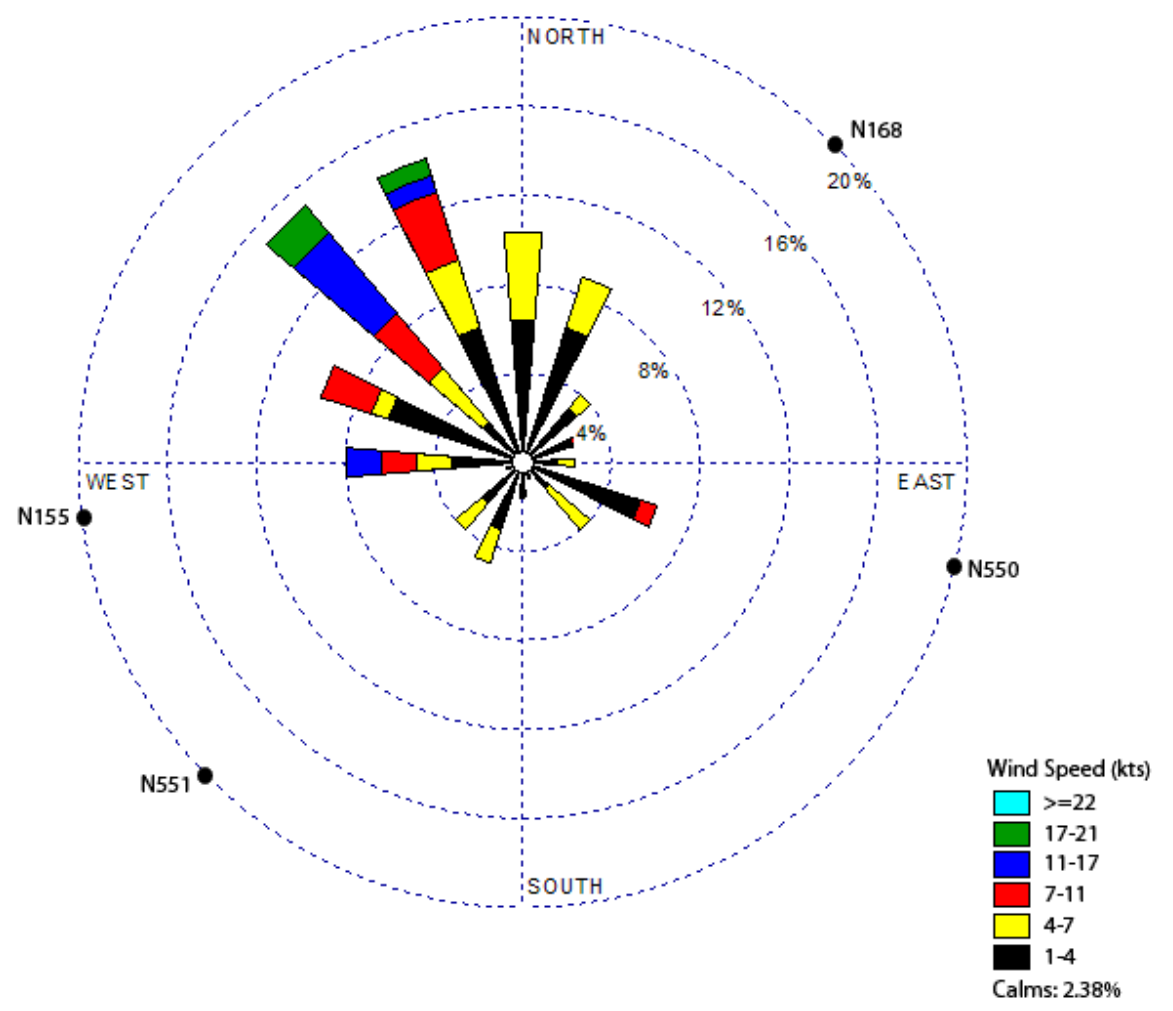

Figure 2.5. Wind Rose for Hanford 200 West Area for Working Hours for the Period August 23-September 7, 2010

\subsection{Air Dispersion Modeling}

The facilities around the $\mathrm{UO}_{3}$ Plant have the potential of affecting dispersion patterns through various meteorological phenomena, including building wake effects. The calculations have been run using the American Meteorological Society/Environmental Protection Agency Regulatory Model (AERMOD), a computer code developed by the U.S. Environmental Protection Agency (EPA). This code calculates dispersion patterns considering building wake effects and other meteorological phenomena. The most recently released version of AERMOD (09292) was used as implemented in AERMOD View Ver. 6.7.1 modeling platform distributed by Lakes Environmental Software Inc. AERMOD information and documentation are available at EPA's website for regulatory air models (EPA 2010). AERMOD is considered a commercial model. For Hanford Site applications, such a model must be tested to ensure it is operating correctly in its current implementation (Project Hanford Management System 2002). A series of test cases distributed with AERMOD obtained from the EPA website (EPA 2010) was run before and after the computations reported here. The AERMOD runs were conducted using a computer (PNNL property number WE13827) with the Windows XP operating system with recent updates installed. Test case results showed the code to be working correctly before and after the production runs.

The emission source area was assumed to be the footprint area for the structures being demolished. The source emissions were modeled as 12 unit-emission point sources distributed over the building areas and adjacent filter housings. This approach differed slightly from the pre-demolition modeling where the maximum potential emissions were assumed to be associated with the filter housings. Sensitivity tests showed that equivalent monitoring results are obtained for both approaches. The current approach was adopted because it represents the entire area with demolition activities. 
Hourly air concentrations were computed at five locations: the N168, N550, and N551 monitoring stations as well as locations near the southwest and northeast corners of the 224-U Building. The hourly predicted concentrations during the entire 10-week period of active demolition for locations N168, N550, and N551 are plotted as a function of wind direction in Figures 2.6 and 2.7 for Scenarios 1 and 2, respectively. All three stations have peaks in concentrations for which the winds can carry any emissions from the demolition area to each of the monitoring stations. In both plots, the N551 peak occurs for more hours and has the largest concentration peaks. N550 and N168 stations have progressively less frequent and lower concentration peaks. These results are consistent with the proximity of the stations to the potential source locations as well the orientation of the buildings to the station locations.

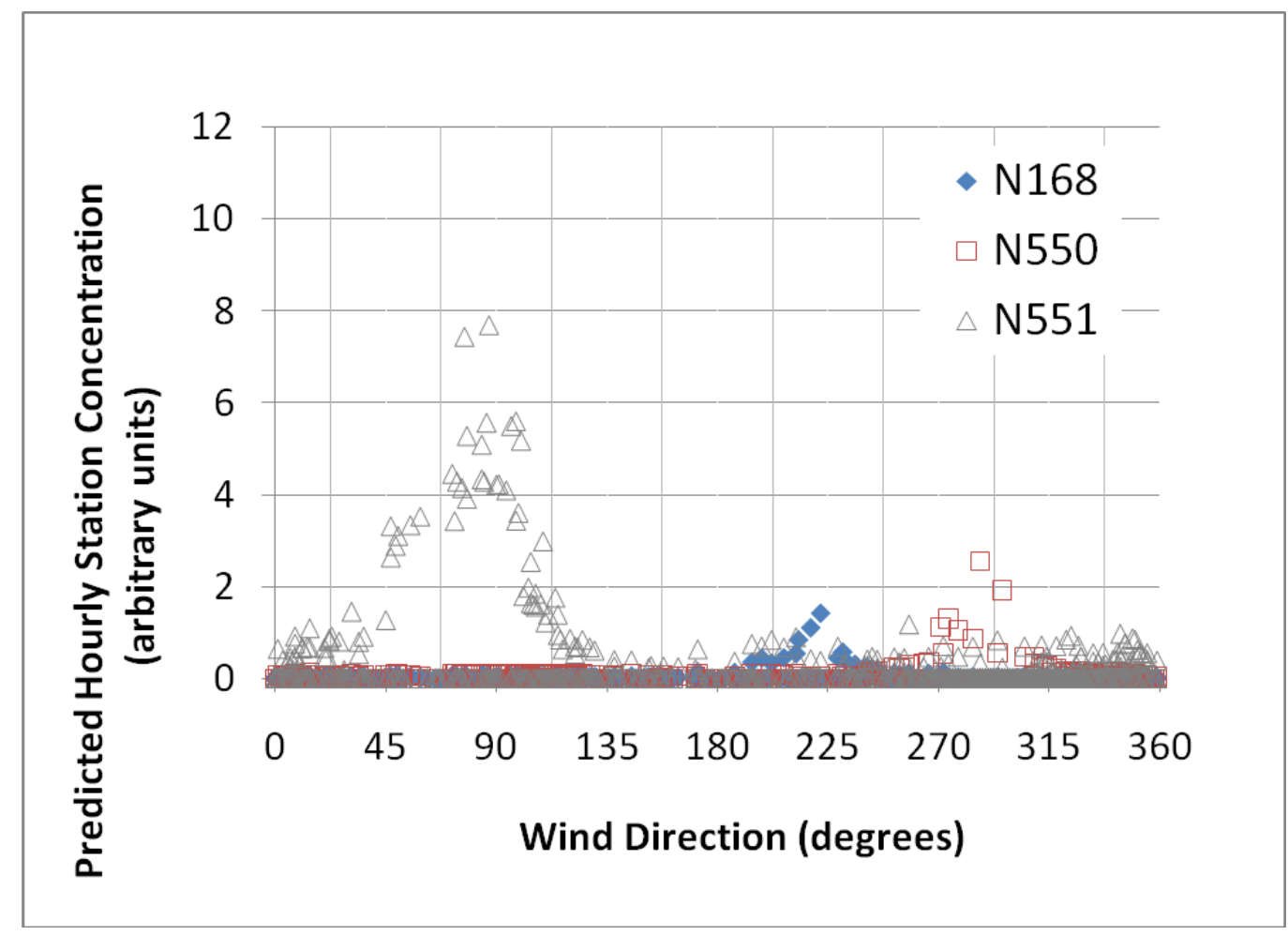

Figure 2.6. Hourly Predicted Air Concentrations as a Function of Wind Direction for Scenario 1

Table 2.1 summarizes the resultant average 2-week concentrations at these locations based on unit releases for the five monitoring periods. The average predicted dispersion conditions for the 10 -week demolition period are shown in Figures 2.8 and 2.9 for Scenarios 1 and 2, respectively. The monitoring station locations are shown as pink square markers; the five square markers include stations N168, N550, and N551, as well as the northeast and southwest corners of the 224-U Building. The source locations are shown as red crosses with a small circle. The average dispersion conditions for each of the five, 2-week periods during the demolition work-hours for Scenarios 1 and 2 are shown in Appendices B and C. Although there is some variation between the results for the 2-week periods, the overall dispersion patterns and rates are very similar with some variations in the average dispersion conditions during the five, 2-week periods. 


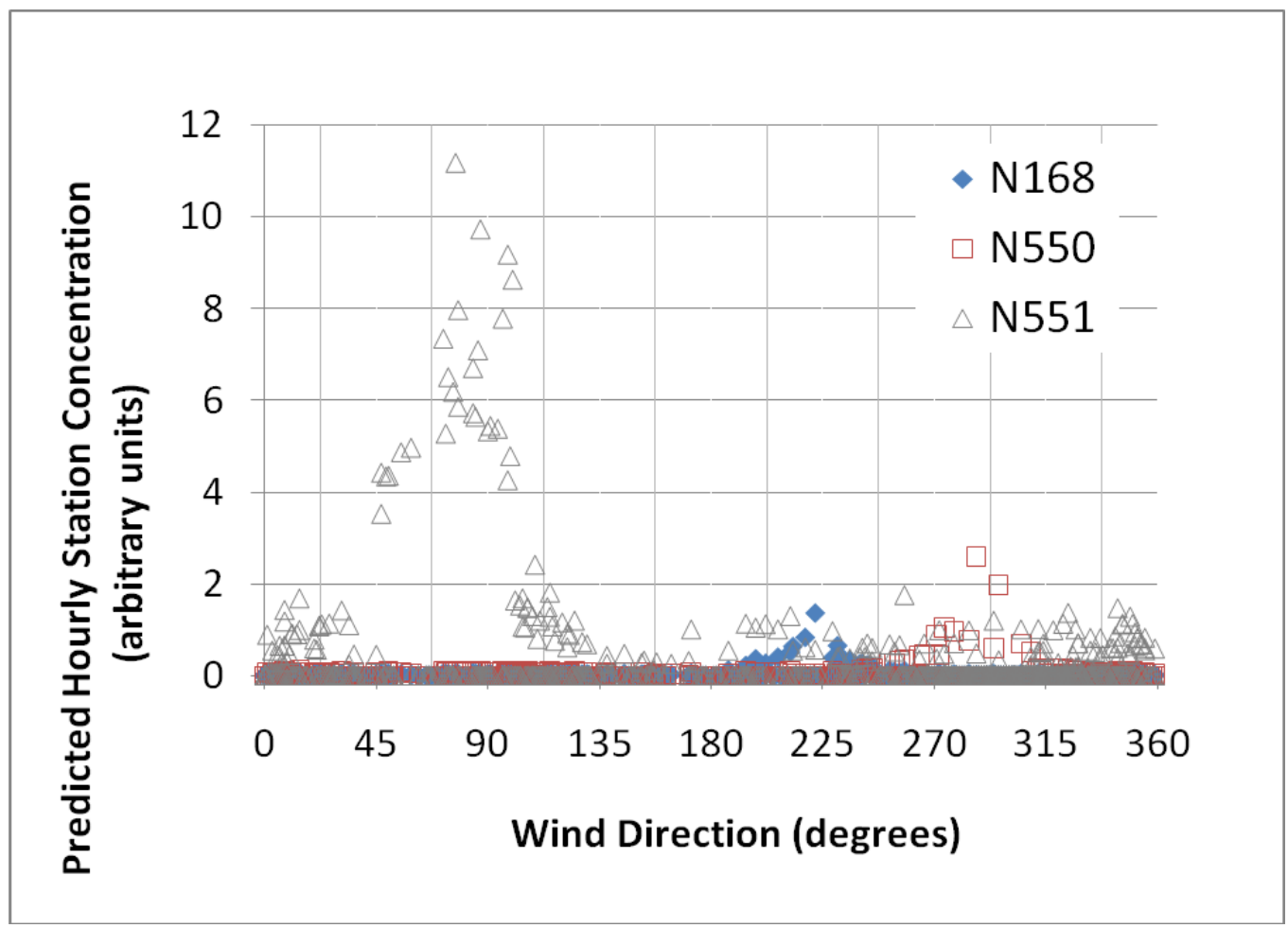

Figure 2.7. Hourly Predicted Air Concentrations as a Function of Wind Direction for Scenario 2

Table 2.1. Predicted Average Air Concentrations for Five, 2-Week Monitoring Periods ${ }^{(a)}$

\begin{tabular}{cccccc}
\hline $\begin{array}{c}\text { Period } \\
\text { Number }\end{array}$ & $\begin{array}{c}\mathrm{N} 168 \\
\left(\mathrm{~g} / \mathrm{m}^{3}\right)\end{array}$ & $\begin{array}{c}\mathrm{N} 550 \\
\left(\mathrm{~g} / \mathrm{m}^{3}\right)\end{array}$ & $\begin{array}{c}\mathrm{N} 551 \\
\left(\mathrm{~g} / \mathrm{m}^{3}\right)\end{array}$ & $\begin{array}{c}\text { NE Corner } \\
\left(\mathrm{g} / \mathrm{m}^{3}\right)\end{array}$ & $\begin{array}{c}\text { SW Corner } \\
\left(\mathrm{g} / \mathrm{m}^{3}\right)\end{array}$ \\
\hline 1 & $1.28 \mathrm{E}-06$ & $1.75 \mathrm{E}-06$ & $1.16 \mathrm{E}-05$ & $3.11 \mathrm{E}-05$ & $1.03 \mathrm{E}-04$ \\
2 & $9.74 \mathrm{E}-07$ & $2.20 \mathrm{E}-06$ & $1.06 \mathrm{E}-05$ & $2.96 \mathrm{E}-05$ & $9.95 \mathrm{E}-05$ \\
3 & $8.70 \mathrm{E}-07$ & $1.19 \mathrm{E}-06$ & $1.89 \mathrm{E}-05$ & $2.85 \mathrm{E}-05$ & $1.38 \mathrm{E}-04$ \\
4 & $1.44 \mathrm{E}-06$ & $1.19 \mathrm{E}-06$ & $1.98 \mathrm{E}-05$ & $4.54 \mathrm{E}-05$ & $1.52 \mathrm{E}-04$ \\
5 & $1.22 \mathrm{E}-06$ & $4.38 \mathrm{E}-06$ & $8.89 \mathrm{E}-06$ & $4.40 \mathrm{E}-05$ & $9.34 \mathrm{E}-05$ \\
\hline
\end{tabular}

(a) Based on a unit release of $1 \mathrm{~g} / \mathrm{s}$.

These modeling results show predicted concentrations of dust from demolition at the 224-U and 224-UA Buildings at the N551 monitoring location that are higher than those predicted at N550 or N168. The results for each of the scenarios are similar but do reflect the use of different source locations. The average difference is about a factor of 10 or more; during periods when the predicted concentrations at N551 are greatest (and most likely to result in an appreciable reading on the N551 detector), those at the other locations are nearly a factor of 1/100 less. 

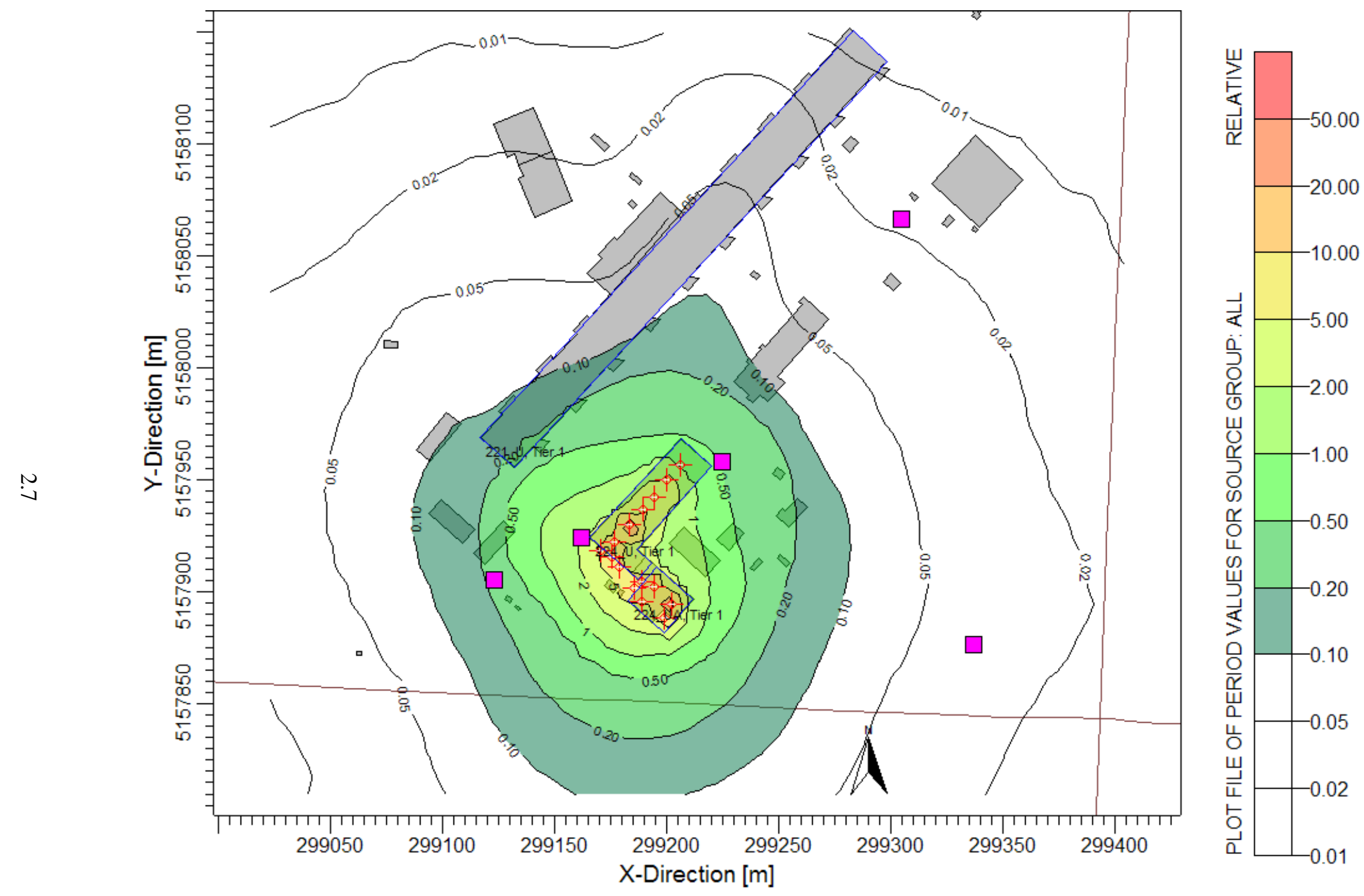

Figure 2.8. Scenario 1 - Average Predicted Concentration Pattern for the 10-Week Demolition Period 

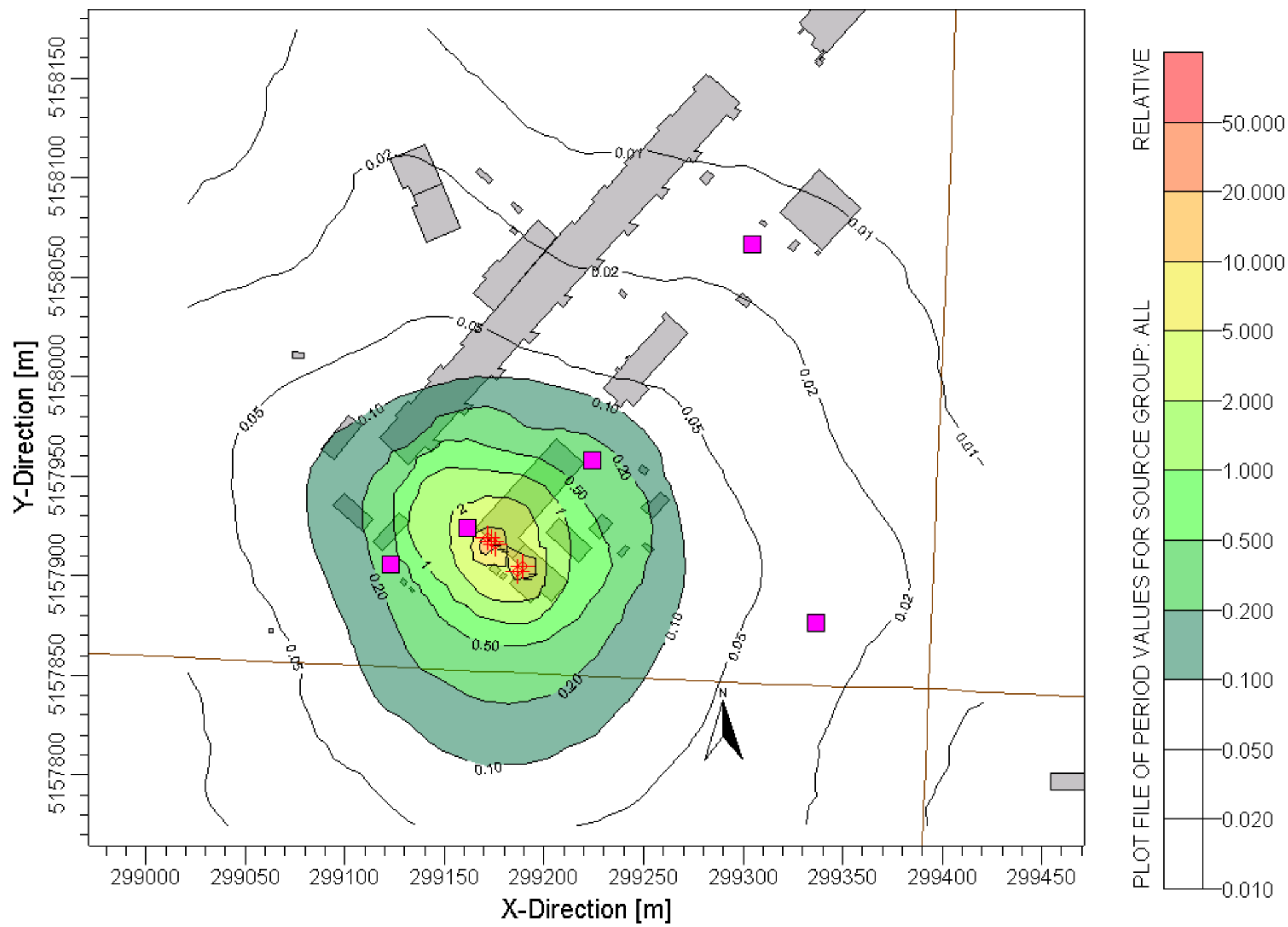

Figure 2.9. Scenario 2 - Average Predicted Concentration Pattern for the 10-Week Demolition Period 


\subsection{Analysis of Gross Alpha Measurements near $\mathrm{UO}_{3}$ Plant Demolition}

The predictions were made for the period from 1 July through 9 September 2010; biweekly measurements are available for this period as well as a long sequence prior to this time. A series of recent measurements including both pre-demoltion and during-demolition periods is shown in Table 3.1. The last five biweekly air sample measurements listed in Table 3.1 were taken during demolition activities and correspond to the five periods listed in Table 2.1.

The demolition activities began in early July 2010; it is apparent that the measurements are not greatly different during the demolition than prior to it. Therefore, a statistical analysis was performed to determine which, if any, of the measurements could reliably be considered to show "detection" of airborne alpha-emitting uranium and its progeny. In particular, it is of interest to know if the monitoring station at location N551, which is predicted to show the largest exposures, is actually indicating detection of radioactive materials above background for the period starting in July 2010.

Table 3.1. Recent Gross-Alpha Measurement Results for Three Air Monitoring Locations

\begin{tabular}{|c|c|c|c|c|c|c|c|}
\hline \multirow{2}{*}{\multicolumn{2}{|c|}{$\begin{array}{l}\text { Sample Collection Period } \\
\text { (Date) }\end{array}$}} & \multicolumn{6}{|c|}{ Concentration } \\
\hline & & \multicolumn{2}{|c|}{ N168 } & \multicolumn{2}{|c|}{ N550 } & \multicolumn{2}{|c|}{ N551 } \\
\hline On & Off & $\begin{array}{c}\alpha \\
(\mu \mathrm{Ci} / \mathrm{cc})\end{array}$ & $\begin{array}{c}\alpha \% \\
\text { Uncert }\end{array}$ & $\begin{array}{c}\alpha \\
(\mu \mathrm{Ci} / \mathrm{cc})\end{array}$ & $\begin{array}{c}\alpha \% \\
\text { Uncert }\end{array}$ & $\begin{array}{c}\alpha \\
(\mu \mathrm{Ci} / \mathrm{cc})\end{array}$ & $\begin{array}{c}\alpha \% \\
\text { Uncert }\end{array}$ \\
\hline 12/28/09 & $01 / 11 / 10$ & $2.6 \mathrm{E}-15$ & 31 & $2.6 \mathrm{E}-15$ & 33 & 3.1E-15 & 32 \\
\hline $01 / 11 / 10$ & $01 / 25 / 10$ & $1.6 \mathrm{E}-15$ & 39 & $3.1 \mathrm{E}-15$ & 84 & $2.4 \mathrm{E}-15$ & 32 \\
\hline $01 / 25 / 10$ & 02/08/10 & 2.1E-15 & 34 & 3.2E-15 & 117 & 1.7E-15 & 38 \\
\hline 02/08/10 & $02 / 22 / 10$ & 7.9E-16 & 73 & $7.4 \mathrm{E}-15$ & 75 & 7.7E-16 & 75 \\
\hline $02 / 22 / 10$ & 03/08/10 & $1.4 \mathrm{E}-15$ & 42 & 3.7E-15 & 84 & 7.3E-16 & 75 \\
\hline 03/08/10 & $03 / 22 / 10$ & 4.2E-16 & 111 & 3.7E-15 & 209 & 8.1E-16 & 73 \\
\hline 03/22/10 & $04 / 05 / 10$ & $1.2 \mathrm{E}-15$ & 47 & $1.7 \mathrm{E}-15$ & 151 & $9.0 \mathrm{E}-16$ & 68 \\
\hline $04 / 05 / 10$ & 04/19/10 & $1.8 \mathrm{E}-15$ & 37 & $2.8 \mathrm{E}-15$ & 108 & $1.1 \mathrm{E}-15$ & 61 \\
\hline 04/19/10 & 05/03/10 & $5.4 \mathrm{E}-16$ & 94 & $5.6 \mathrm{E}-15$ & 97 & $1.6 \mathrm{E}-15$ & 40 \\
\hline 05/03/10 & 05/17/10 & $1.2 \mathrm{E}-15$ & 47 & $5.8 \mathrm{E}-15$ & 39 & $9.4 \mathrm{E}-16$ & 73 \\
\hline $05 / 17 / 10$ & 06/01/10 & 8.5E-16 & 63 & $3.8 \mathrm{E}-16$ & 108 & $9.2 \mathrm{E}-16$ & 61 \\
\hline 06/01/10 & $06 / 14 / 10$ & 7.5E-17 & 427 & $1.0 \mathrm{E}-15$ & 62 & 1.7E-15 & 41 \\
\hline $06 / 14 / 10$ & $06 / 28 / 10$ & 5.5E-16 & 94 & $1.4 \mathrm{E}-15$ & 41 & $1.2 \mathrm{E}-15$ & 45 \\
\hline 06/28/10 & $07 / 12 / 10$ & $1.1 \mathrm{E}-15$ & 47 & $1.4 \mathrm{E}-15$ & 45 & 3.8E-15 & 26 \\
\hline 07/12/10 & $07 / 26 / 10$ & 1.9E-15 & 36 & 2.9E-15 & 117 & 5.4E-15 & 23 \\
\hline $07 / 26 / 10$ & 08/09/10 & 7.5E-16 & 73 & $2.6 \mathrm{E}-15$ & 84 & 6.7E-15 & 22 \\
\hline 08/09/10 & $08 / 24 / 10$ & $1.4 \mathrm{E}-15$ & 39 & $2.4 \mathrm{E}-15$ & 75 & 4.0E-15 & 25 \\
\hline $08 / 24 / 10$ & 09/09/10 & $1.1 \mathrm{E}-15$ & 46 & $3.1 \mathrm{E}-15$ & 82 & 2.1E-15 & 36 \\
\hline
\end{tabular}

In making low-level radioactivity measurements of populations, it is commonly observed that a substantial portion of net results is negative. Furthermore, the observed variance of the measurement 
results arises from a combination of measurement uncertainty and population variability. Recently, a method was developed for disaggregating measurement uncertainty from population variability to produce a probability density function (PDF) of possibly true results. ${ }^{1}$ To do this, simple, justifiable, and reasonable assumptions are made about the relationship of the measurements to the measurands (the "true values"). The measurements are assumed to be unbiased - that is, that their average value is the average of the measurands. Using traditional estimates of each measurement's uncertainty to disaggregate population variability from measurement uncertainty, a PDF of measurands for the population is produced. Then, using Bayes' theorem, the same assumptions, and all the data from the population of individuals, a prior PDF is computed for each individual's measurand. These PDFs are non-negative, and their average is equal to the average of the measurement results for the population. In this analysis, the methods are applied to baseline gross alpha air monitoring data from the Hanford Site.

The measurements of gross alpha (which would include uranium from the demolition), a sample of which is shown in Table 3.1, show some variability with moderately large uncertainties. The region around the Hanford U-Plant has been used for uranium processing in the past, and there is background uranium in local soils that can be suspended by the wind. In order to determine if there is a statistical likelihood that the during-demolition measurements differ from the expected background, a Bayesian disaggregation of the uncertainties of the individual measurements and the variability of the historical measurements was performed. The result of the statistical analysis for monitoring station N551 is shown in Figure 3.1. In this figure, the five panels represent the statistical separation of the background distribution and the measurement with its uncertainty. The mean of background samples is about $1.2 \times$ $10^{-15} \mu \mathrm{Ci} / \mathrm{ml}$.

The fact that the N551 measurements during demolition clearly do not coincide with the distribution of pre-demolition measurenents indicates that there is a high statistical likelihood that the five measurements taken during periods with demolition activities are greater than the local background. This is shown in a different manner in Figure 3.2. In Figure 3.2, the analysis results for station N551 for each of the available air sample measurements are plotted. The plot is of the statistically determined Bayesian "true value” (in International Organization for Standardization terminology, the "measurand”) of the measurement plotted against the measured value and its uncertainty. The measurements taken during demolition are highlighted; it is apparent that for station N551, these measurements are among the highest values measured. The first four have a very high probability of being actual detections of alpha air concentration above background; the final one is not significantly elevated.

Plots similar to those for station N551 are given in Figure 3.3 for locations N550, N168, and N155. The five during-demoliton samples from N155 and N168 are distributed within the variability of historical background. The during-demoltion samples from N550 show some trend toward being higher than normal but are still within the range of background variability. These plots confirm the calculated plots of Figure 2.5; the results of the modeling for N551 indicate that there should be low but detectable levels at N551, and the modeling for the other locations indicates that measurements should be essentially background. Location N550 may have some indications of measureable concentrations in both the modeling and monitoring.

\footnotetext{
${ }^{1}$ Strom DJ, K Joyce, J MacLellan, DJ Watson, T Lynch, C Antonio, A Birchall, and P Zharov. 2010. “Disaggregating Measurement Uncertainty from Population Variability and Bayesian Treatment of Uncensored Results.” Submitted to Radiation Protection Dosimetry. (In press)
} 

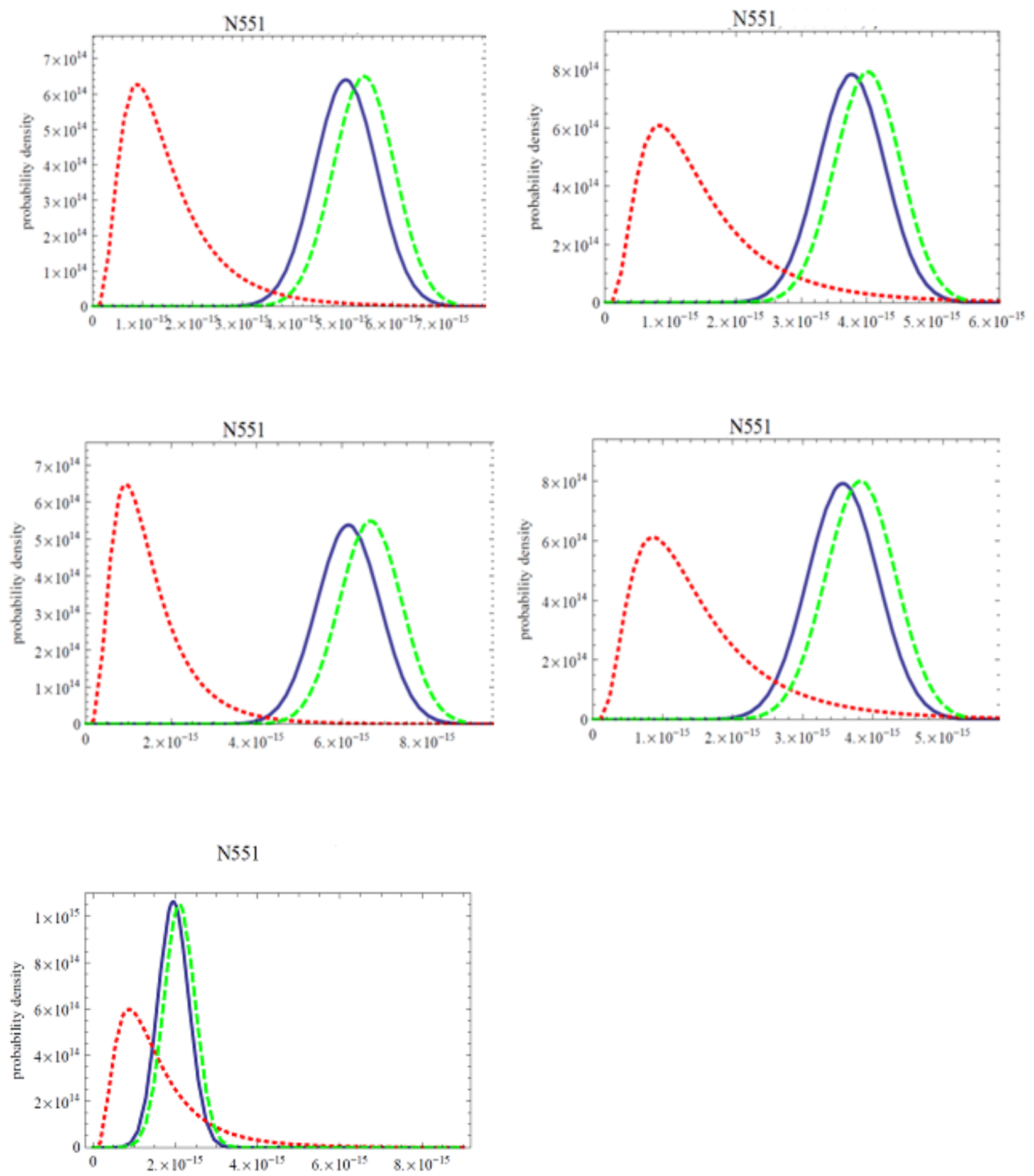

Figure 3.1. Comparison of Probability Density Functions for Five Measurements of Gross Alpha Concentration from Monitoring Station N551 to the Background of All Measurements from that Station. Dotted red curves are the background distribution, dashed green curves are the reported measurement with its reported uncertainty, solid blue curves are the Bayesian statistical likelihood functions for the true value of the measurements. Units are $\mu \mathrm{Ci} / \mathrm{ml}$. 


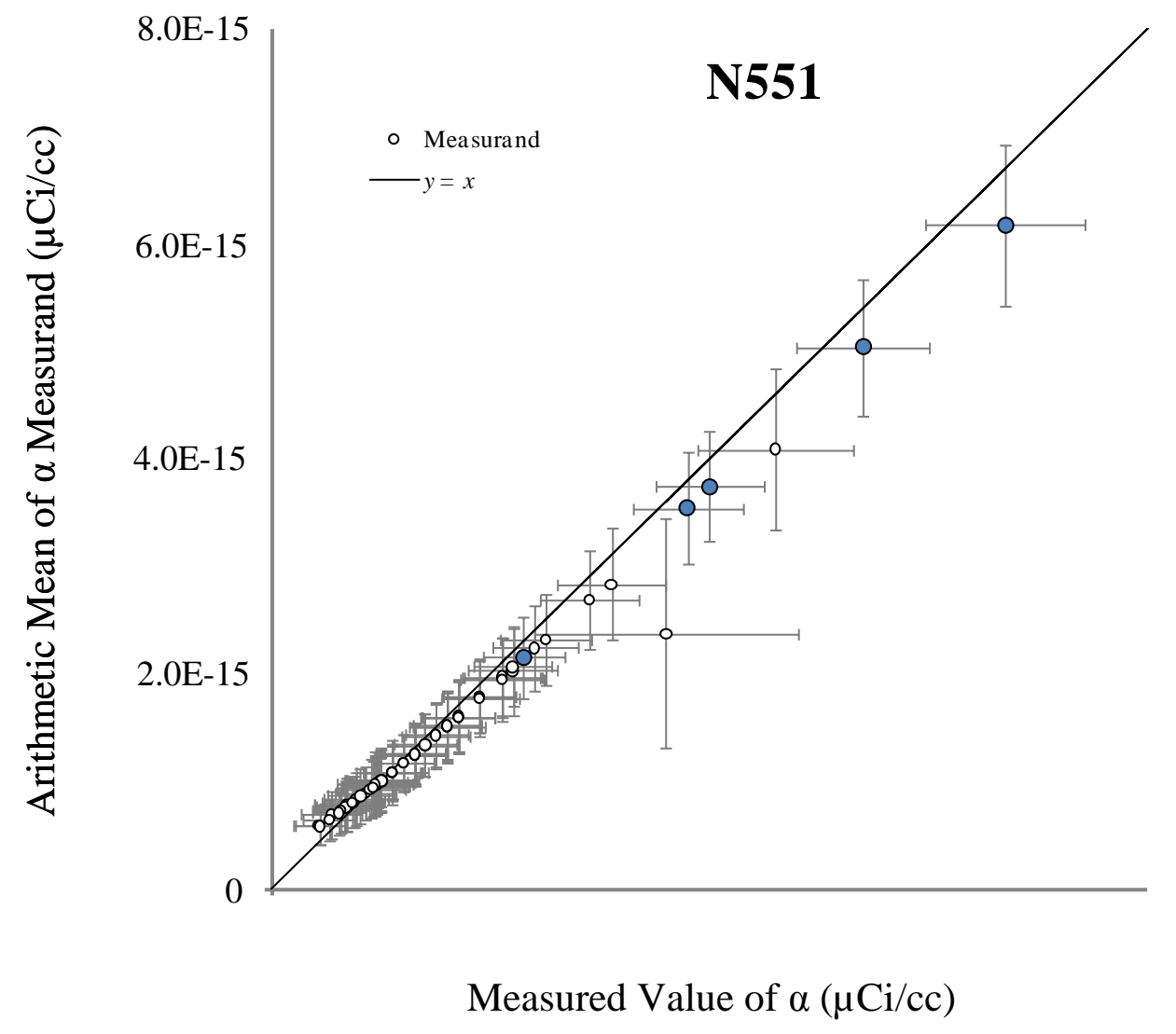

Figure 3.2. Statistical Separation of Variability and Uncertainty of Airborne Gross Alpha Measurements for Monitoring Station N551. The five measurements taken during demolition of 224-U and 224-UA are highlighted in blue. 

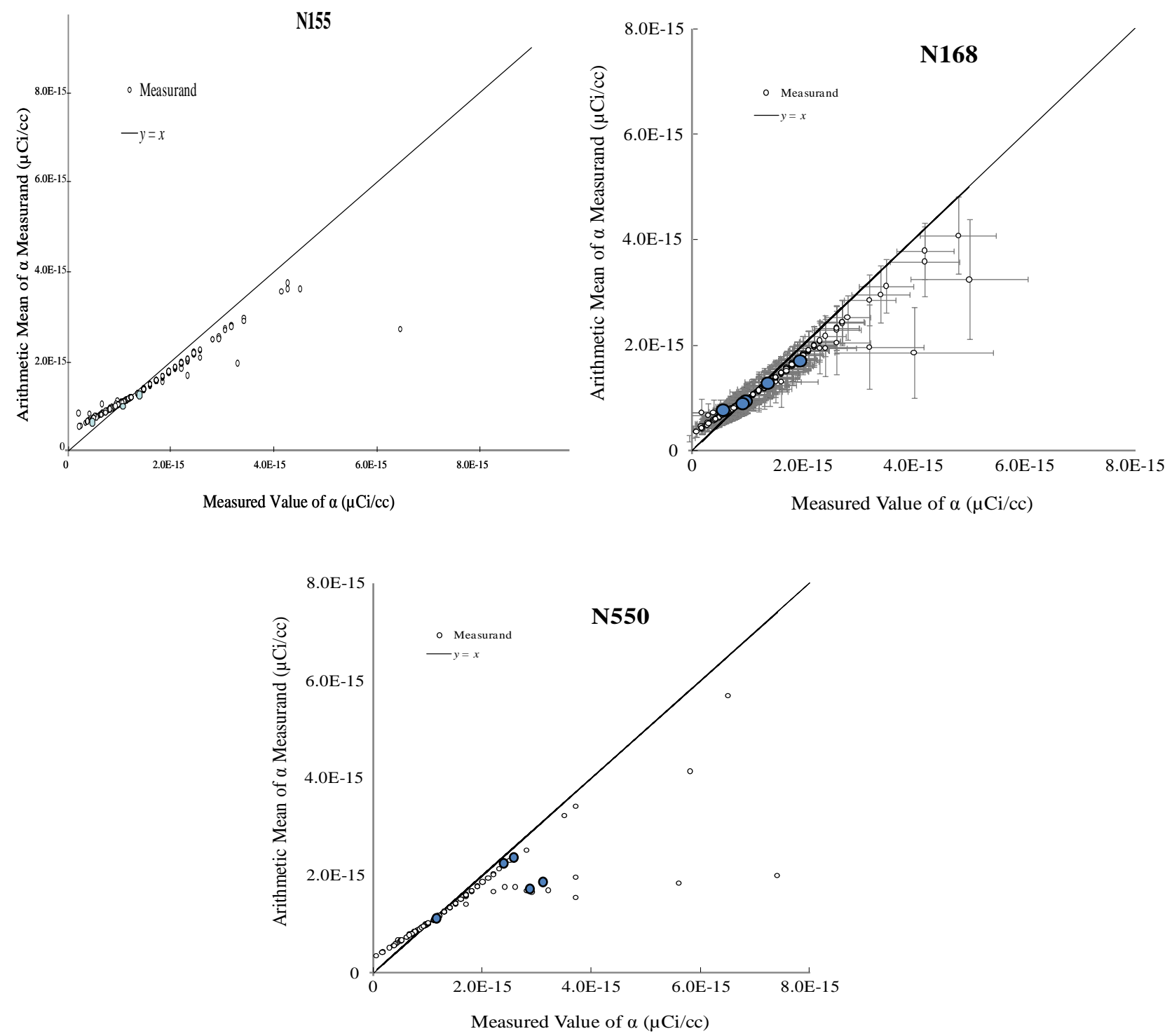

Figure 3.3. Statistical Separation of Variability and Uncertainty of Airborne Gross Alpha Measurements for Monitoring Stations N155, N168, and N550. The five measurements taken during demolition of 224-U and 224-UA are highlighted in blue. 


\subsection{Modeled and Monitored Data Comparison}

A comparison of the observed concentrations to the predicted values for the two source area scenarios is presented in Figures 4.1 and 4.2. Because the calculations were performed for a unit release of dust and the measurements are for activity concentration, the values have been normalized. In the normalization, it has been assumed that the average background of alpha concentration is $1.2 \times 10^{-15} \mu \mathrm{Ci} / \mathrm{ml}$ and that this constitutes one arbitrary unit. The median value of the predictions has been set so that it "matches" the observation; all other values are then determined from this relationship. If all of the measurements matched the predictions, the results would fall along a straight line at 45 degrees in these figures. Both Figures 4.1 and 4.2 show that the monitoring station at location N168 is measuring essentially background for this period; the station at N550 may be slightly above background, but still in the uncertainty range, and the station at N551 is in reasonable agreement with the predictions.

The pre-demolition modeling analysis (Napier et al. 2009) assumed a total emission of $48 \mathrm{~g}$ of uranium. Concentrations that were slightly elevated over background were observed. The air concentrations computed in the pre-demolition modeling analysis are consistent with the elevated monitored air concentrations observed during actual demolition.

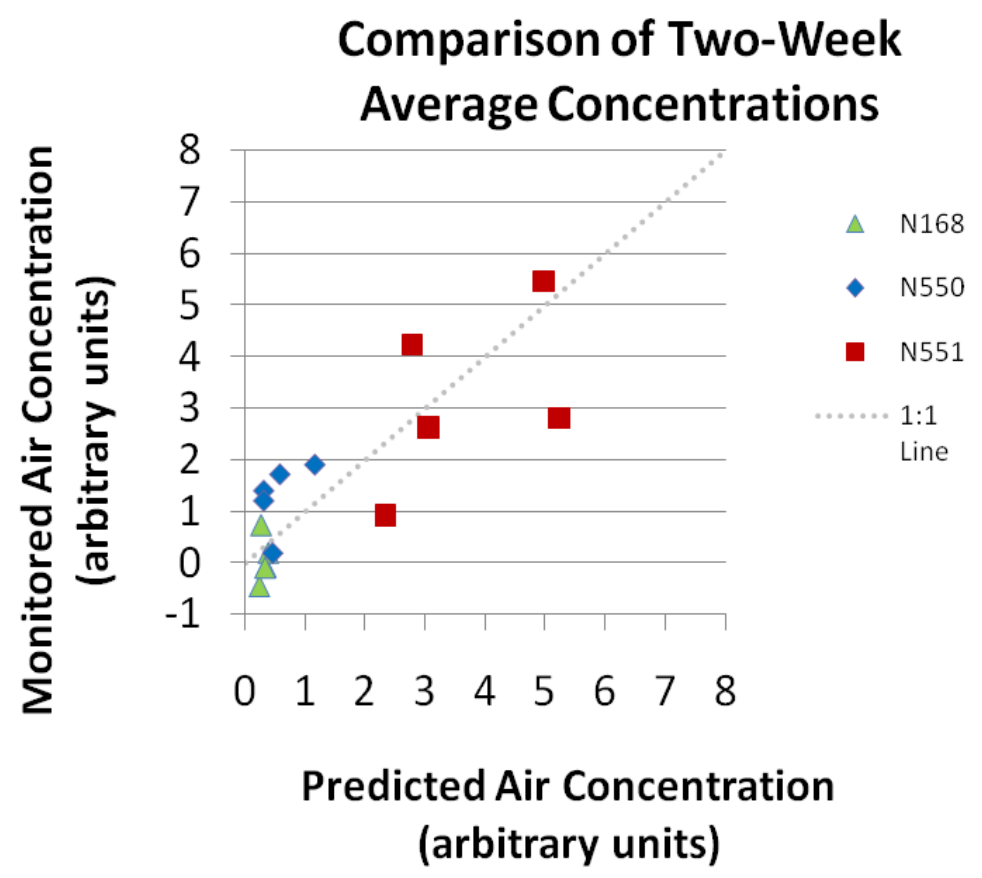

Figure 4.1. Comparison of Predicted and Observed Concentrations of Gross Alpha at the Air Monitoring Locations for Scenario 1 (Building Area Source) 


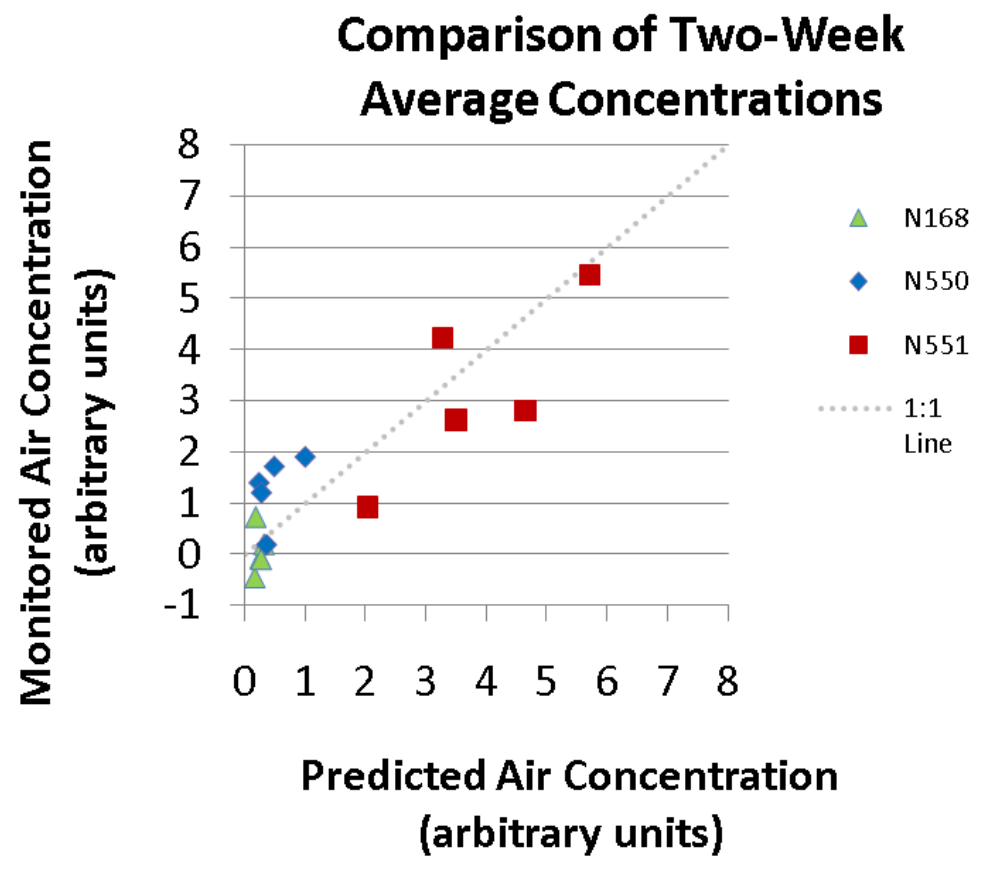

Figure 4.2. Comparison of Predicted and Observed Concentrations of Gross Alpha at the Air Monitoring Locations for Scenario 2 (Baghouse area source) 


\subsection{Conclusions}

The modeling of the demolition of the 224-U and 224-UA Buildings assumed there would be some release of radioactive material into the air (Napier et al. 2009). Monitoring performed around the facilities during the period of active demolition, and afterwards, has indicated slightly elevated levels of gross alpha - correlated with uranium releases - at the monitoring station location N551. Using the meteorological observations for each of the 2-week monitoring periods and assuming a uniform release from the demolition over the sampling time periods, it has been shown that the model would predict slightly elevated concentrations at this location, and not at others nearby. These elevated concentrations correspond to the preferred downwind direction for the time periods under consideration. The agreement with the monitoring data is slightly better assuming the emissions are from the more-contaminated baghouse areas rather than from the entire footprint of the demolished buildings. These results are highly consistent with the interpretation that the slightly elevated concentrations are the result of the demolition activities.

The consistency of the pre-demolition concentration predictions and the concentration increments observed during the demolition indicate the validity and value of the pre-demolition computations for planning demolition activities. 


\subsection{References}

EPA - U.S. Environmental Protection Agency. 2010. Technology Transfer Network Support Center for Regulatory Air Models. Available at http://www.epa.gov/scram001/ (August 2010).

Napier BA, JP Rishel, and JG Droppo Jr. 2009. Analysis of Radioactive Releases during Proposed Demolition Activities for the 224-U and 224-UA Buildings. PNNL-18332, Pacific Northwest National Laboratory, Richland, Washington.

Project Hanford Management System. 2002. Computer Software Management. HNF-PRO-309, Fluor Hanford, Inc. Richland, Washington. 
Appendix A

\section{Emission Scenarios Analysis}




\section{Appendix A - Emission Scenarios Analysis}

To allow a comparison of predicted concentrations and monitoring data, assumptions must be made about both when and where the emissions occur. The monitoring data during the demolition consistently tend to have the highest concentrations at N551, second highest at N550, and lowest at N168. Figure A.1 provides a comparison of the predicted concentrations for several modeling scenarios considered in this analysis.

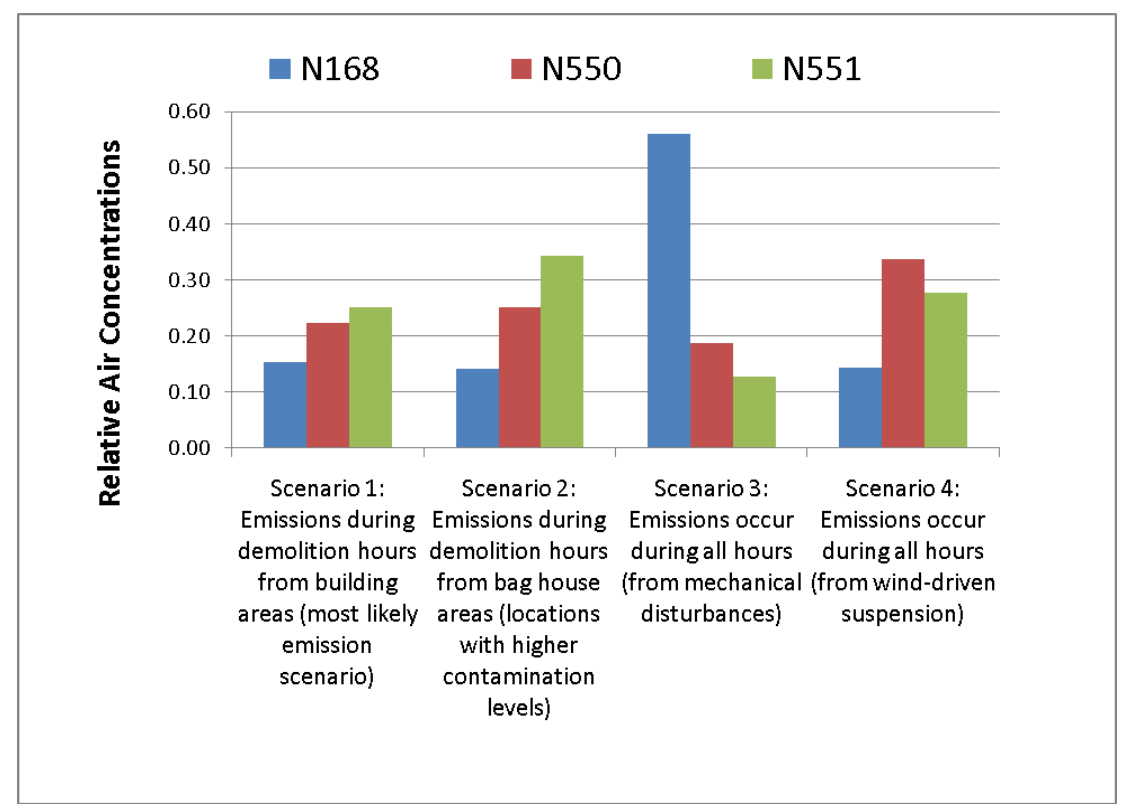

Figure A.1. Relative Contibutions to Monitoring Stations for Various Modeling Scenarios

The first scenario assumes that the emissions come primarily from the building structures during the demolition working hours. For that scenario, the variations in predicted concentrations match the pattern of the monitoring data. This scenario was selected for use in the modeling effort. The second scenario is the same case - except the emissions come mainly from the filter housing locations - smaller areas where the highest levels of contamination are expected to be encountered. The second scenario has trends very similar to the first scenario.

Two additional scenarios are based on the assumption that the emissions are from some mechanism other than the demolition activities. The third and fourth scenarios assume the emissions from the building areas occur uniformly 24-hours per day from suspension by mechanical disturbances and wind action, respectively. Neither of these scenarios has predicted concentration increments that match the measured concentraton trends during the five periods with demolition activities (as seen in Table 3.1) and thus do not appear to be viable scenarios for the modeling comparison effort.

Of the four emission scenarios considered, the results indicate that the first two are the most viable scenarios for modeling the source of the observed elevated concentrations. As a result, these two scenarios were selected for the detailed modeling efforts presented in this report. 
Appendix B

\section{Building Area Source Predicted Concentrations}




\section{Appendix B - Building Area Source Predicted Concentrations}
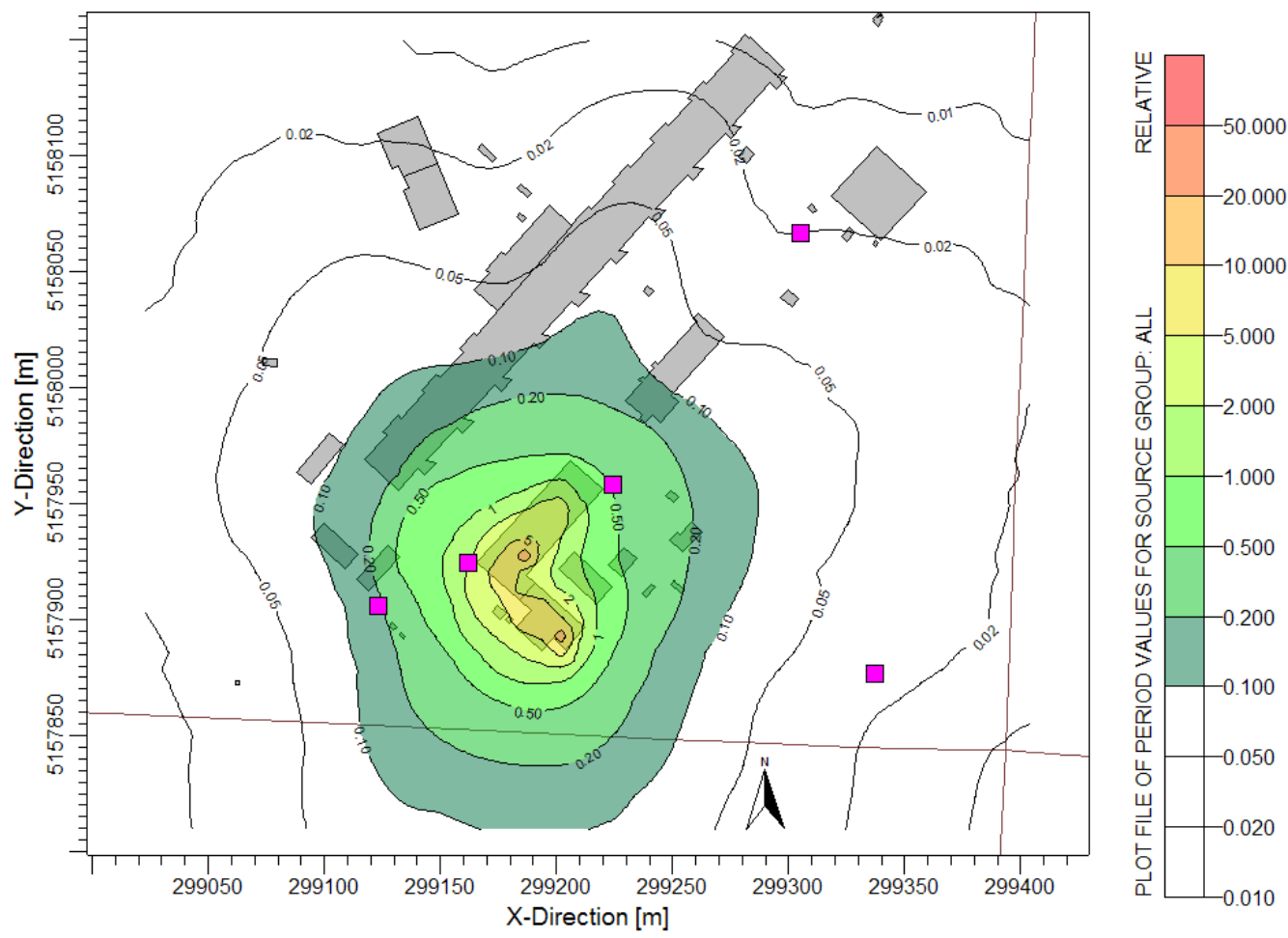

Figure B.1. Average Predicted Concentration Pattern for Demolition for Scenario 1 During Period 1 

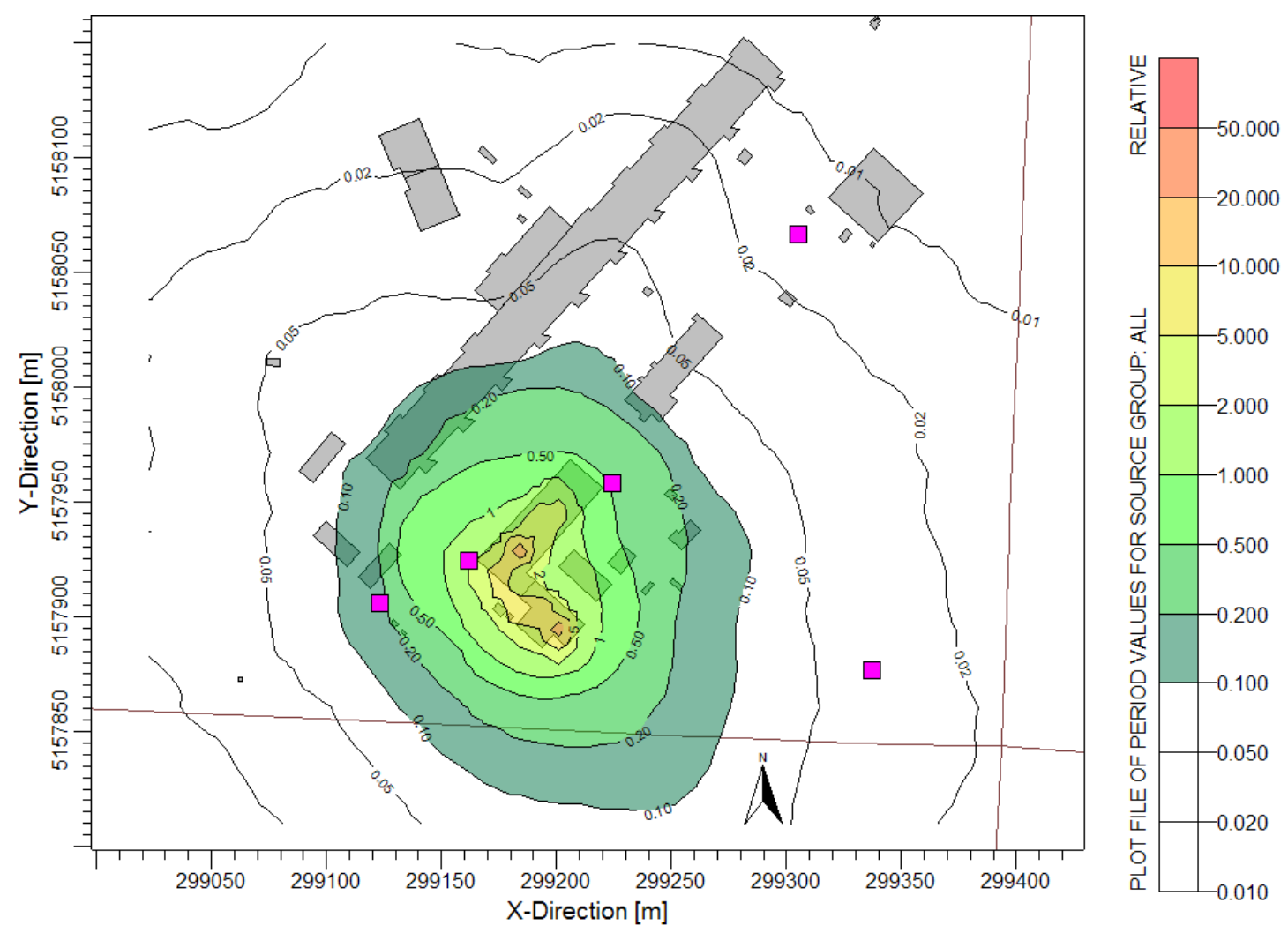

Figure B.2. Average Predicted Concentration Pattern for Demolition for Scenario 1 During Period 2
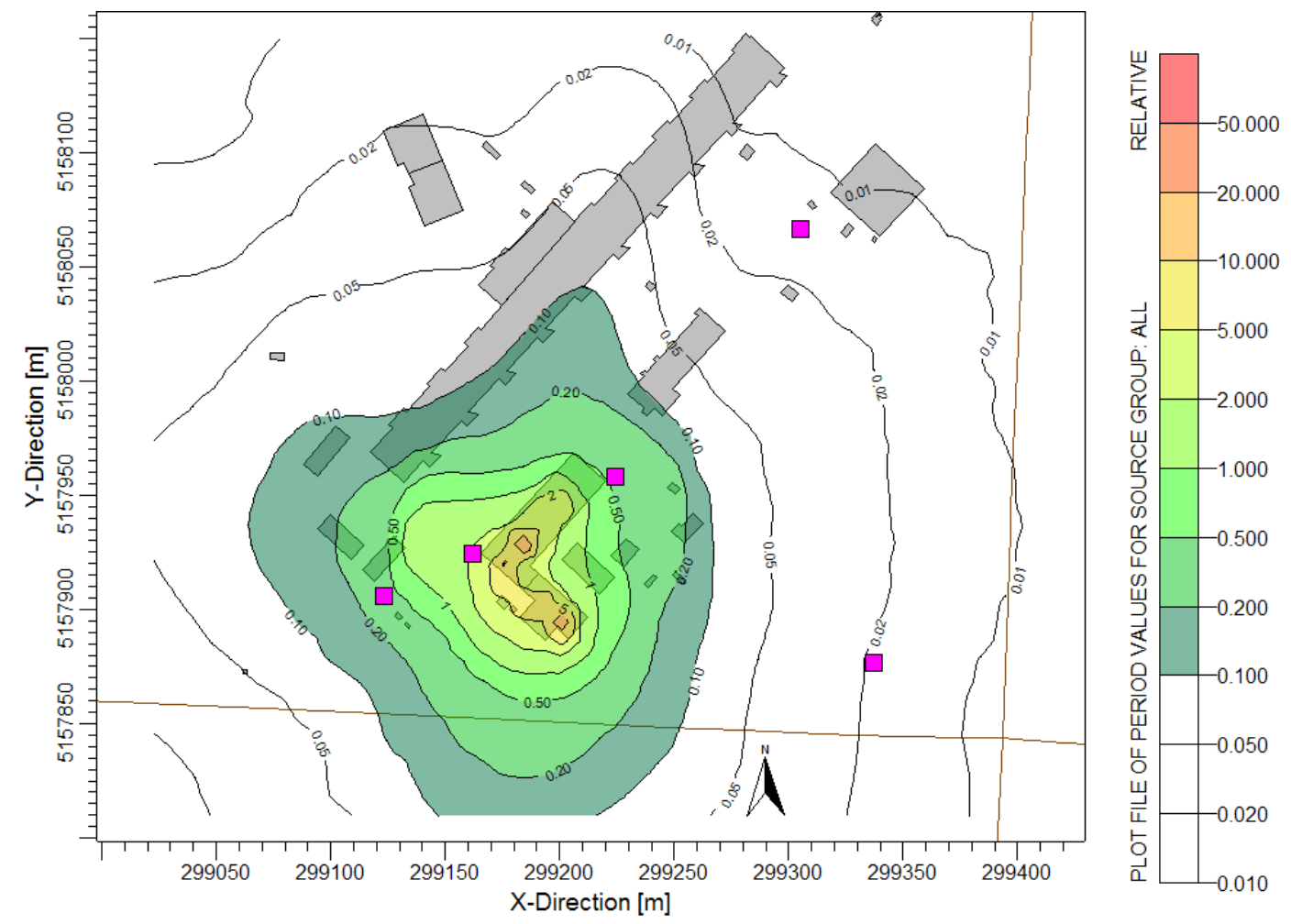

Figure B.3. Average Predicted Concentration Pattern for Demolition for Scenario 1 During Period 3 

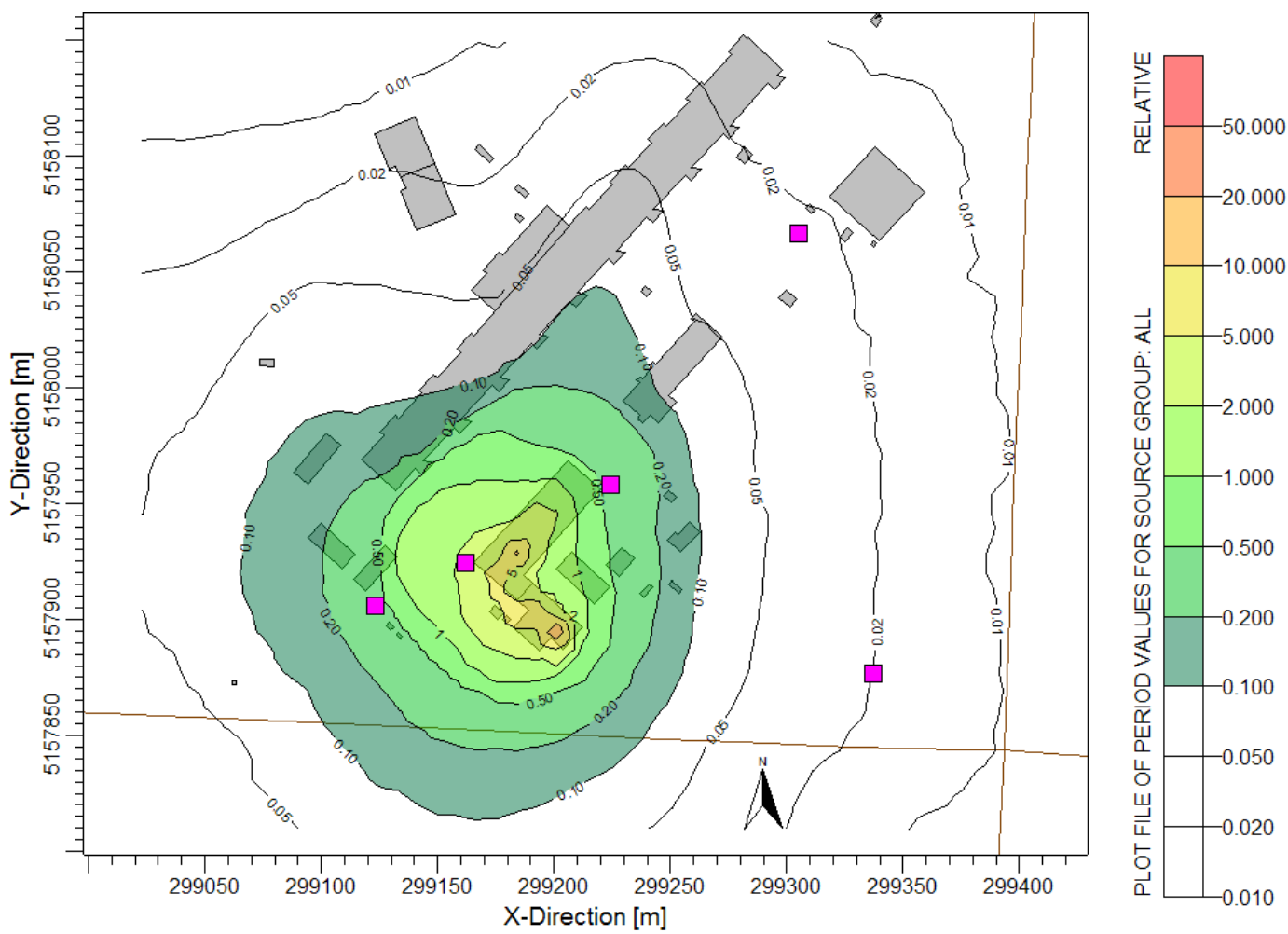

Figure B.4. Average Predicted Concentration Pattern for Demolition for Scenario 1 During Period 4
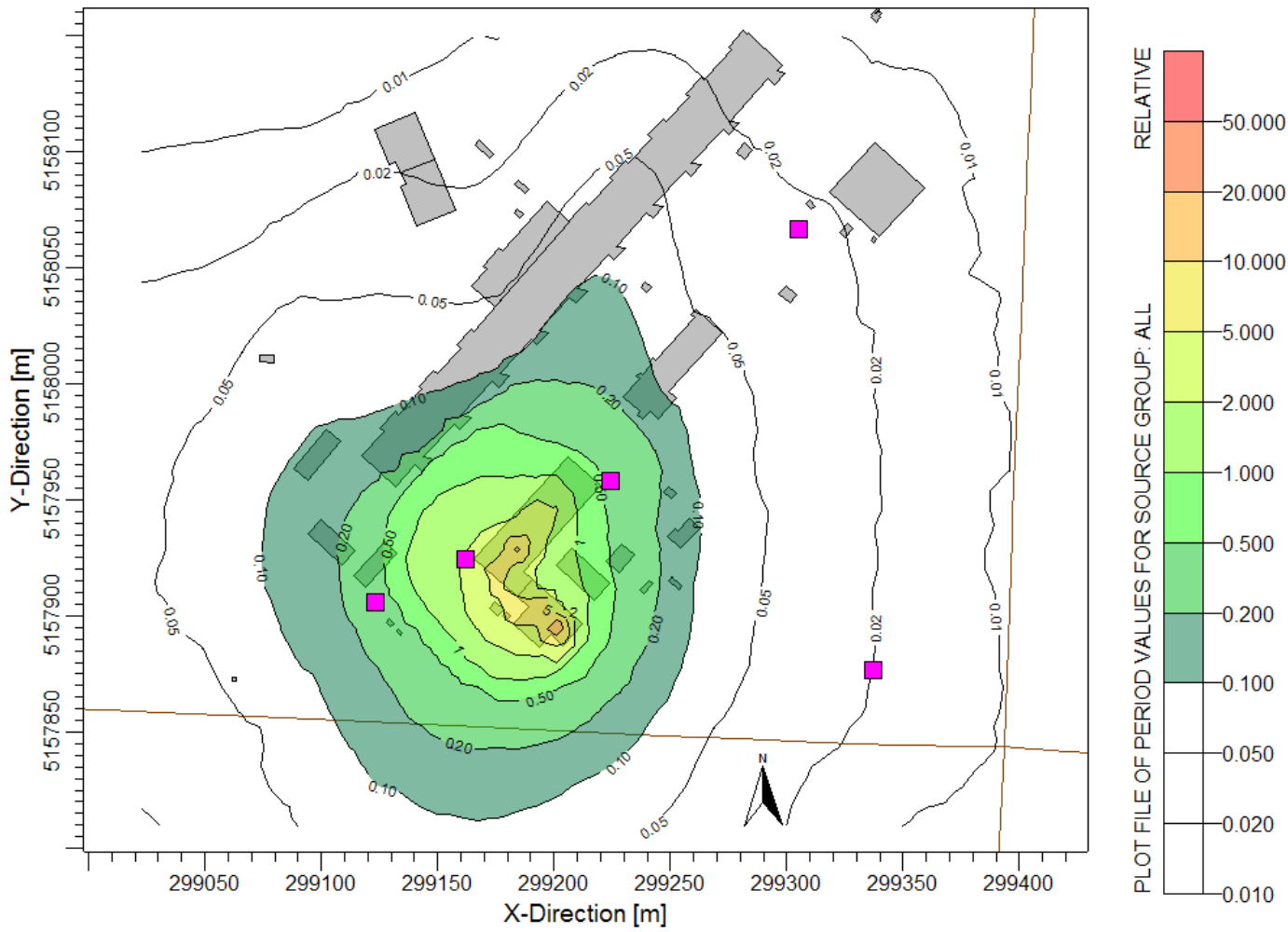

Figure B.5. Average Predicted Concentration Pattern for Demolition for Scenario 1 During Period 5 
Appendix C

Baghouse Source Predicted Concentrations 


\section{Appendix C - Baghouse Source Predicted Concentrations}

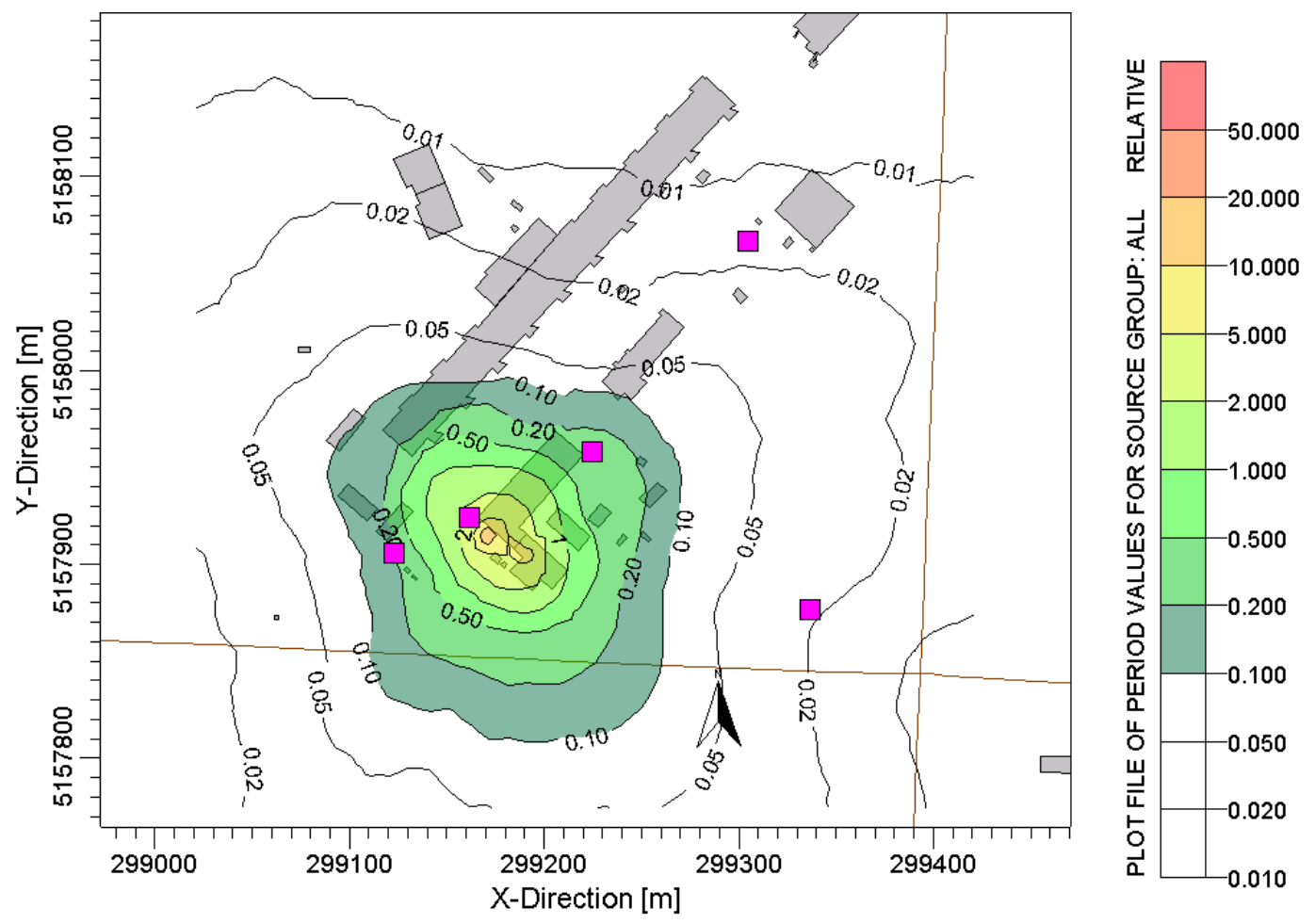

Figure C.1. Average Predicted Concentration Pattern for Demolition Period 1
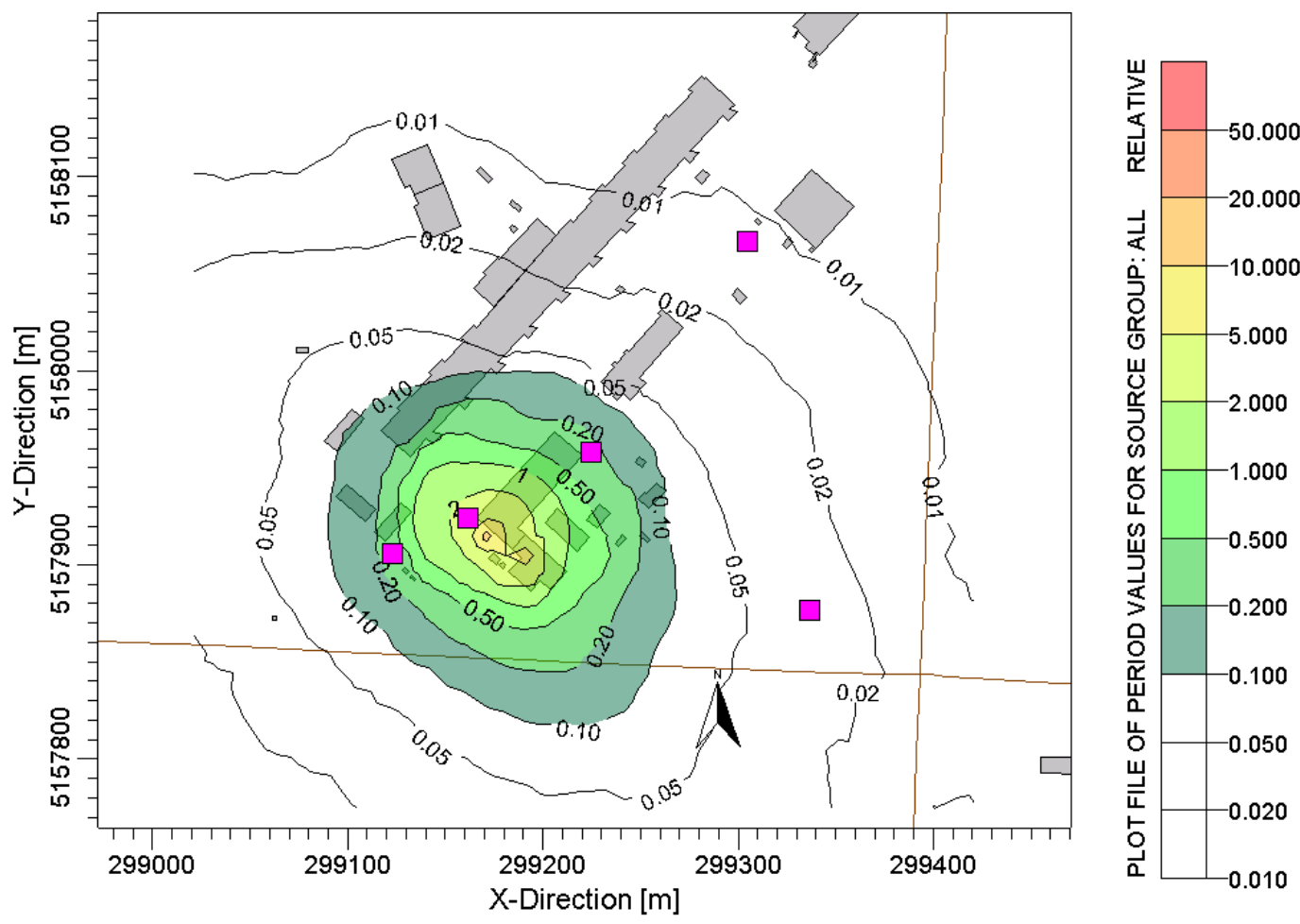

Figure C.2. Average Predicted Concentration Pattern for Demolition Period 2 

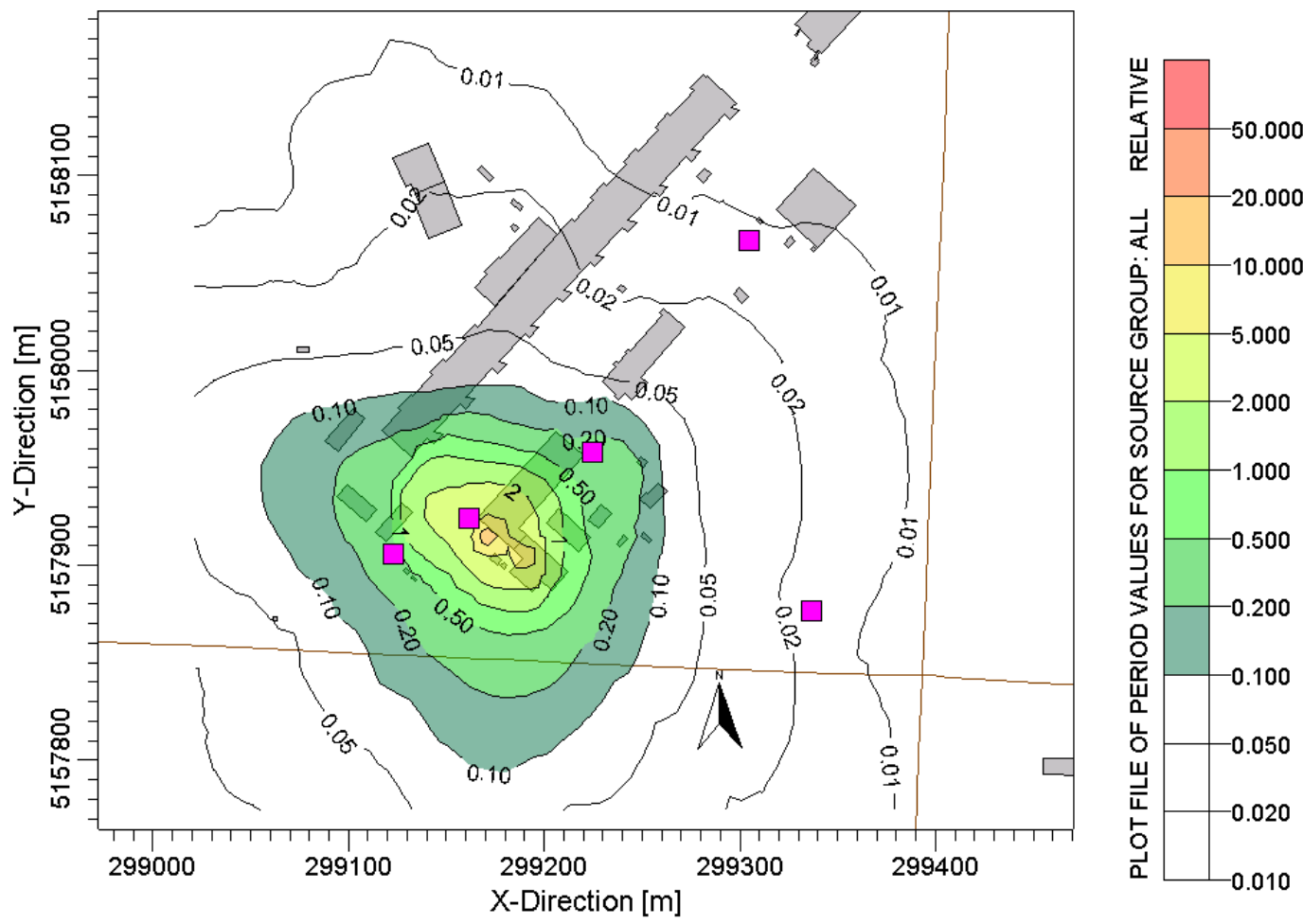

Figure C.3. Average Predicted Concentration Pattern for Demolition Period 3
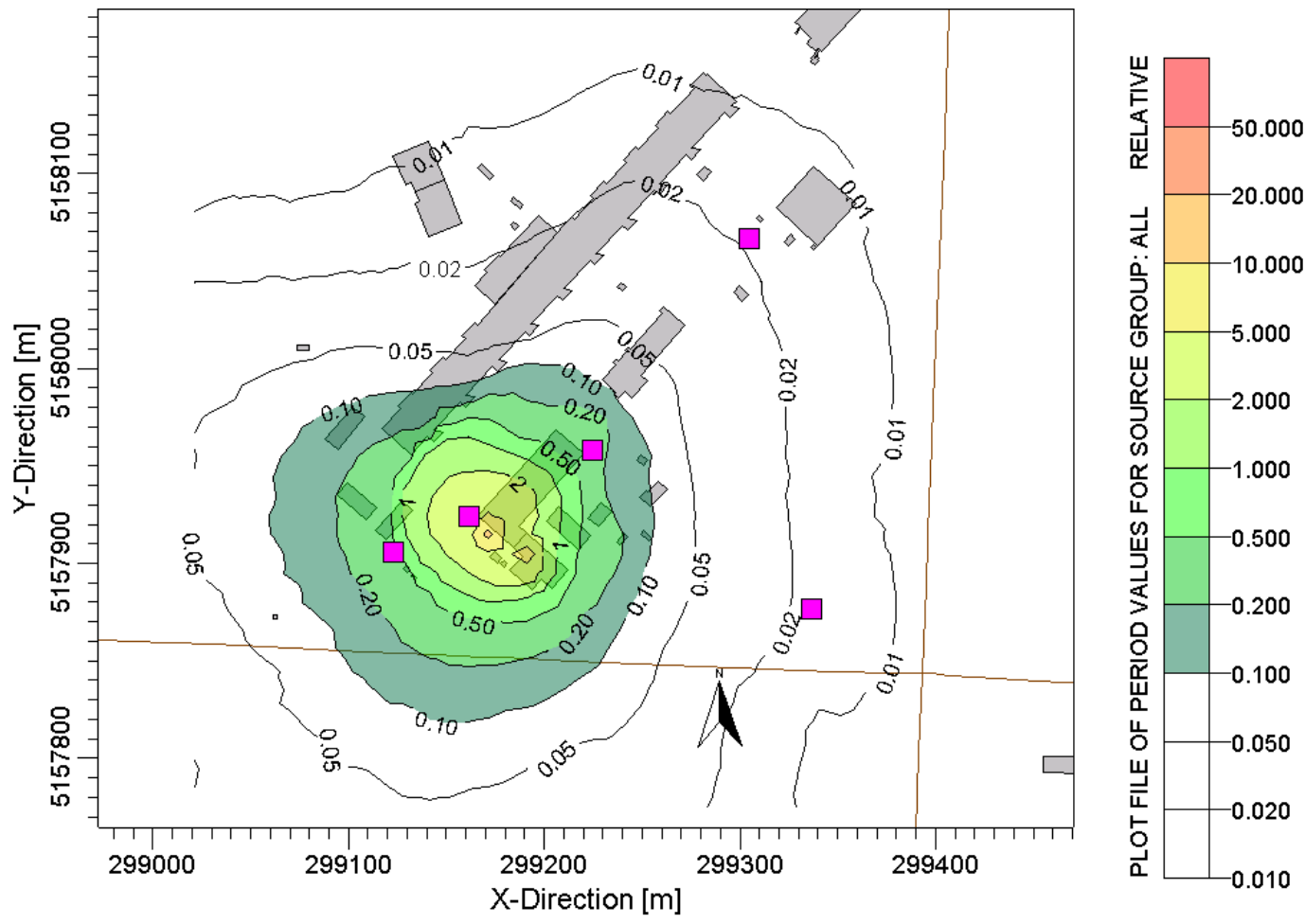

Figure C.4. Average Predicted Concentration Pattern for Demolition Period 4 

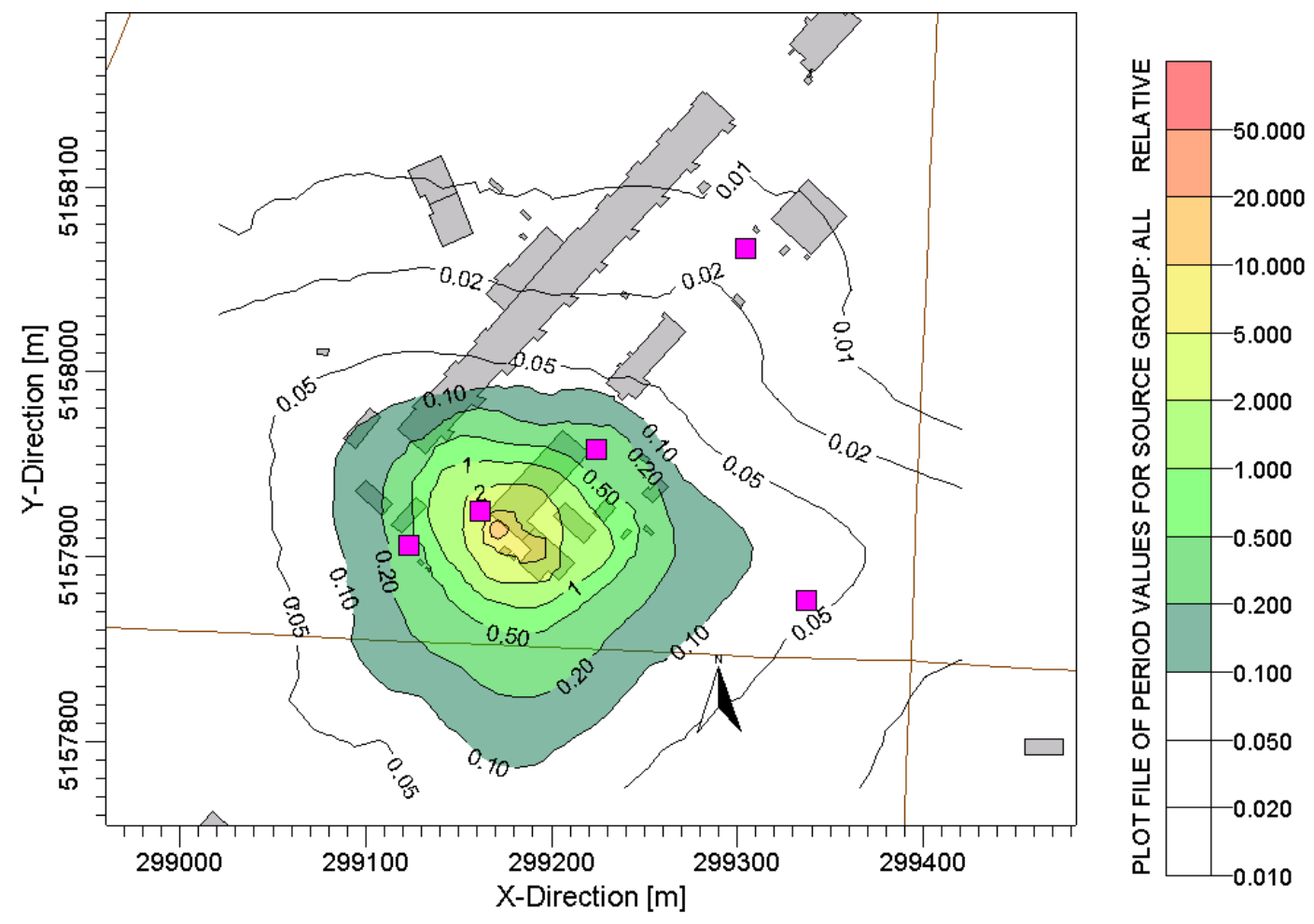

Figure C.5. Average Predicted Concentration Pattern for Demolition Period 5 
PNNL-18332

Addendum

\section{Distribution}

No. of

Copies

9 CH2M HILL Plateau Remediation Company

DD Alt

RW Bloom

GT Chandler

ER Lloyd

AM Nazarali

M Stevens

CB Walker

RE Wilkinson

LC Zinsli
No. of

Copies

2 Pacific Northwest National Laboratory

JG Droppo (2)

K9-30

BA Napier

JP Rishel

(PDF)

(PDF)

DJ Strom

KE Joyce

T4-35

T1-41

S2-42

T1-40

T4-35

T4-35

T1-41

Distr.1 


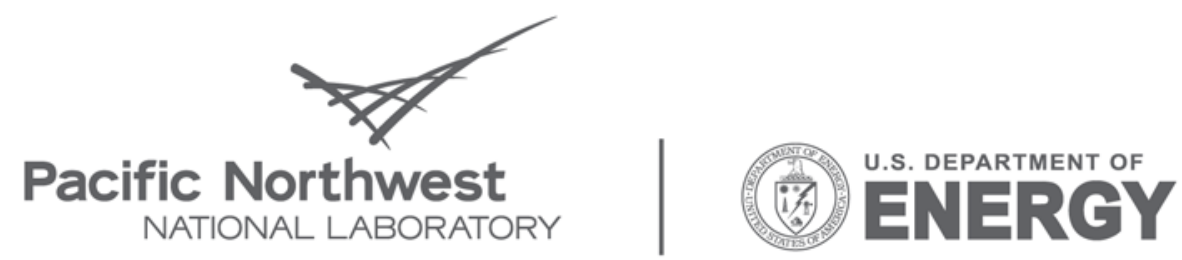

Proudly Operated by Battelle Since 1965

902 Battelle Boulevard

P.O. Box 999

Richland, WA 99352

1-888-375-PNNL (7665)

www.pnl.gov 